ISSN 1678-3921

Journal homepage: www.embrapa.br/pab

For manuscript submission and journal contents, access: www.scielo.br/pab

\section{Plant-mycorrhizal fungi interaction and response to inoculation with different growth-promoting fungi}

\begin{abstract}
The symbiotic interaction between arbuscular mycorrhizal fungi (AMF) and 70-90\% of the plant species is largely studied, but ectomycorrhizal fungi, Piriformospora indica, Trichoderma sp., and dark septate endophytes (DSE), also establish beneficial interactions with plants. Despite this, the joint discussion on the biochemical, physiological, and molecular aspects of nutrient transfer, mainly from the extraradical mycelium (ERM) to the plant, is still limited. The objective of this review is to present biochemical, physiological, and molecular approaches to the plant-AMF interaction, as well as to analyze the response of plants to inoculations with different growthpromoting fungi. Here, are highlighted the characteristics of the $\mathrm{H}^{+}$-ATPases and of the transporters of $\mathrm{NH}_{4}{ }^{+}$and $\mathrm{H}_{2} \mathrm{PO}_{4}{ }^{-}$involved in the absorption of phosphorus and nitrogen by the soil through the ERM of the AMF, besides the biochemical aspects of the metabolism of both nutrients in the ERM and their translocations from the ERM to the intraradical mycelium and to the host plant. Finally, the nitrogen fertilizer recovery efficiency in plants inoculated with AMF, Trichoderma sp., P. indica, and DSE fungi is presented. By examining, together, the biochemical, physiological, and molecular aspects of the plant-AMF interaction and the nitrogen fertilizer recovery efficiency in inoculated plants, it is possible to conclude that a low-input agriculture could be achieved with the use of these fungi in agrosystems.
\end{abstract}

Index terms: Piriformospora indica, Trichoderma harzianum, arginine, dark septate fungi, $\mathrm{H}^{+}$-ATPases, nutrient transporters.

\section{Introduction}

Several plant species establish associations with a series of microorganisms that can result in beneficial interactions to both symbionts (Oldroyd, 2013). These interactions between fungi and plants are diverse, from mutualistic to pathogenic, causing devastating crop diseases. Although plant diseases are well known and economically important, the fact that plants without infections - by both endophytic and mycorrhizal fungi - are rare or do not exist is not widely recognized.

One of the most studied symbiotic interactions involving fungi occurs between plants and arbuscular mycorrhizal fungi (AMF) (Oldroyd, 2013). The arbuscular mycorrhiza is a very old symbiosis between obligate biotrophic fungi of the phylum Glomeromycota, such as AMF, and $70-90 \%$ of the plant species, mediated through the twoway transfer of nutrients between the host and AMF (Smith \& Read, 2008; Smith \& Smith, 2012). It is believed that this symbiosis facilitated 
soil colonization by plants that evolved from aquatic environments approximately 450 million years ago (Redecker et al., 2000). It should be noted that other groups of fungi also form symbiotic associations with plants, such as ectomycorrhizal fungi (ECM), Piriformospora indica, Trichoderma sp., and dark septate endophytic fungi; however, unlike AMF, these fungi are not obligate biotrophs.

The exchange of chemical signals between plants and AMF leads to the formation of the arbuscular mycorrhiza (Bonfante \& Requena, 2011; Oldroyd, 2013). The initial step in this communication is the release of strigolactone in the rhizosphere by plant roots (Oldroyd, 2013) (Figure 1 A). Strigolactone promotes the germination of spores and stimulates the branching of the hyphae in AMF (Bonfante \& Genre, 2010; Harrison, 2012; Oldroyd, 2013), which produce mycorrhizal factors, including lipochitooligosaccharides and chitooligosaccharides, which are recognized by host plants and activate the signaling pathway of the symbiosis in the root, leading to oscillations in calcium contents (Maillet et al., 2011; Genre et al., 2013).

The physical contact between AMF and the plant root surface allows of the formation of a globular fungal structure of infection, the hyphopodium ( $1 \mathrm{~B}$ ), also called appressorium (Bonfante \& Genre, 2010), whose penetration is facilitated by signals released by the plant cutin (Wang et al., 2012). Since the cell walls of the epidermis are penetrated, the fungus grows inter- or intracellularly, creating invaginations in the cytoplasm, spreading through the root cortex (Bonfante \& Genre, 2010). Then, within the cells of the cortex, they form highly enveloped hyphae structures, called platoons, or highly branched hyphae structures, called arbuscules (Harrison, 2005; Parniske, 2008) (Figure $1 \mathrm{C}$ ), which act as haustoria. The development of the arbuscules is accompanied by the invagination of the cell membrane of the plant, forming the periarbuscular membrane (Figure $1 \mathrm{~B}$ ), which is distinct from the cell membrane (Pumplin \& Harrison, 2009). The arbuscule, together with the periarbuscular membrane, forms a large nutrient exchange interface (Parniske, 2008; Bonfante \& Genre, 2010).

With the establishment of the arbuscular mycorrhizal symbiosis, modifications in the gene expression of the plant and fungus occur, accompanied by the morphological and physiological changes necessary

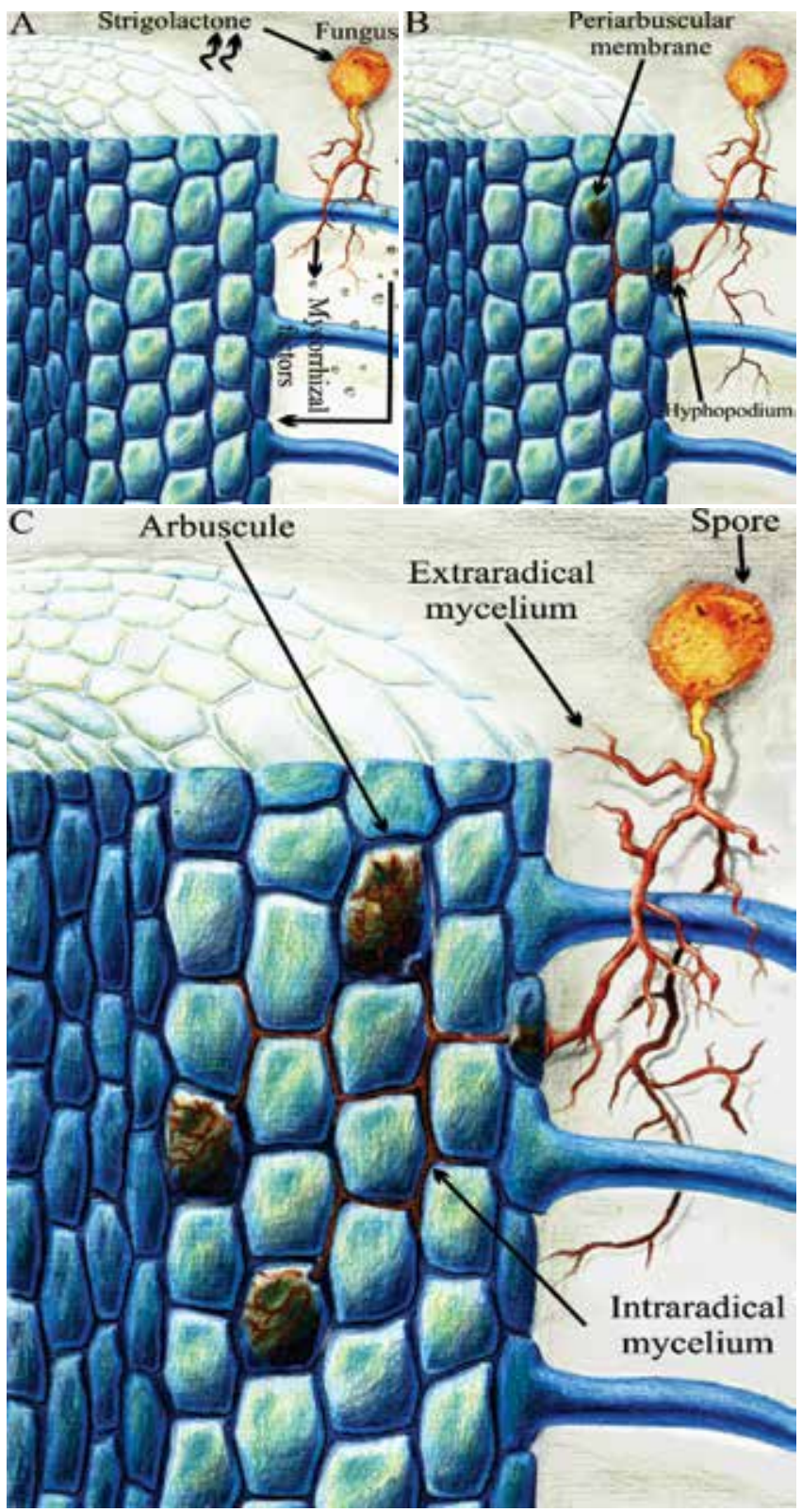

Figure 1. Hypothetical root colonized by an arbuscular mycorrhizal fungus (AMF): A, the root of the host plant signals that it is apt to establish arbuscular mycorrhizal symbiosis, by releasing strigolactone, which promotes the germination of the fungal spores and stimulates the branching of the extraradical mycelium of the AMF, and the fungus responds with the production of the mycorrhizal factors (lipo-chitooligosaccharides and chitooligosaccharides) that are recognized by the host plant; and B and C, the physical contact between the root surface and the AMF allows of the formation of the hyphopodium, which leads to the intercellular proliferation of the intraradical mycelium in the cortex cells and to the intracellular development of the arbuscules surrounded by the periarbuscular membrane derived from the plasma membrane of the plant cell. 
for the two-way transfer of nutrients between the symbionts (Requena et al., 2003). The absorption of $\mathrm{H}_{2} \mathrm{PO}_{4}^{-}$is considered a key physiological process through which AMF promote plant growth (Bucher, 2007). Indeed, AMF express $\mathrm{H}_{2} \mathrm{PO}_{4}{ }^{-}$transporters able to absorb this ion from the soil and allow its release to the interface with the plant (Harrison \& Van Buuren, 1995). Additionally, the plant has transporters that are specific to the arbuscular mycorrhiza interface, whose role is to absorb $\mathrm{H}_{2} \mathrm{PO}_{4}^{-}$ions from the periarbuscular space and release them to the plant cytoplasm (Guether et al., 2009). Similarly, AMF can promote plant growth through the transfer of nitrogen (Govindarajulu et al., 2005; Jin et al., 2005; Guether et al., 2009; Smith \& Smith, 2011), which is also absorbed by the extraradical mycelium (López-Pedrosa et al., 2006) and released in the periarbuscular space by transporters located in the intraradical mycelium (Govindarajulu et al., 2005). Subsequently, nitrogen is transferred to the cytosol by plant transporters specific to the arbuscular mycorrhiza interface (Guether et al., 2009).

The objective of this review is to present biochemical, physiological, and molecular approaches to the plantAMF interaction, from the absorption of phosphorus and nitrogen by the extraradical mycelium to the twoway transfer of these nutrients among the symbionts, besides analyzing the plant response to inoculation with different growth-promoting fungi.

\section{Mycorrhizal roots feature two pathways for nutrient absorption}

AMF live in two environments: in plant roots, where they receive organic carbon; and in the soil, where they absorb mineral nutrients (Smith \& Smith, 2011). The intraradical mycelium grows in an environment controlled by plant homeostasis, while the extraradical one lives under considerable environmental variations, such as soil pH, moisture, and nutrient availability (Smith \& Smith, 2011).

The major advantage of mycorrhizal roots in relation to the nonmycorrhizal ones is that the former present two nutrient absorption pathways (Figure 2): through the plant and through AMF (Smith \& Smith, 2011; Bücking $\&$ Kafle, 2015). Through the fungus, this pathway involves: nutrient absorption through the extraradical mycelium; its rapid translocation, sometimes of many centimeters, towards the intraradical mycelium; its release into the periarbuscular space; and its transfer to the plants (Smith \& Smith, 2011; Bücking \& Kafle, 2015). The periarbuscular membrane, which surrounds the arbuscules and the intracellular hyphae (Pumplin \& Harrison, 2009), contains the $\mathrm{H}_{2} \mathrm{PO}_{4}^{-}$(Javot et al., 2007; Volpe et al., 2016), $\mathrm{NH}_{4}^{+}$(Guether et al., 2009; Pérez-Tienda et al., 2014), and $\mathrm{NO}_{3}{ }^{-}$(Drechsler et al., 2018) transporters, preferentially or specifically expressed in mycorrhizal roots, as well as proton pumps $\left(\mathrm{H}^{+}\right.$-ATPases) that drive the transport of nutrients (Gianinazzi-Pearson et al., 1991, 2000; Krajinski et al., 2014; Wang et al., 2014). The plant absorbs nutrients from the rhizosphere through the transporters that are located in the epidermis and in the root hairs (Smith \& Smith, 2011; Bücking \& Kafle, 2015).

\section{Absorption and translocation of $\mathrm{H}_{2} \mathrm{PO}_{4}^{-}$through the extraradical mycelium, AMF arbuscule, and periarbuscular space}

In a study with radioisotopes, it was concluded that the extraradical mycelium was responsible for the absorption of $\mathrm{H}_{2} \mathrm{PO}_{4}^{-}$ions, which are subsequently

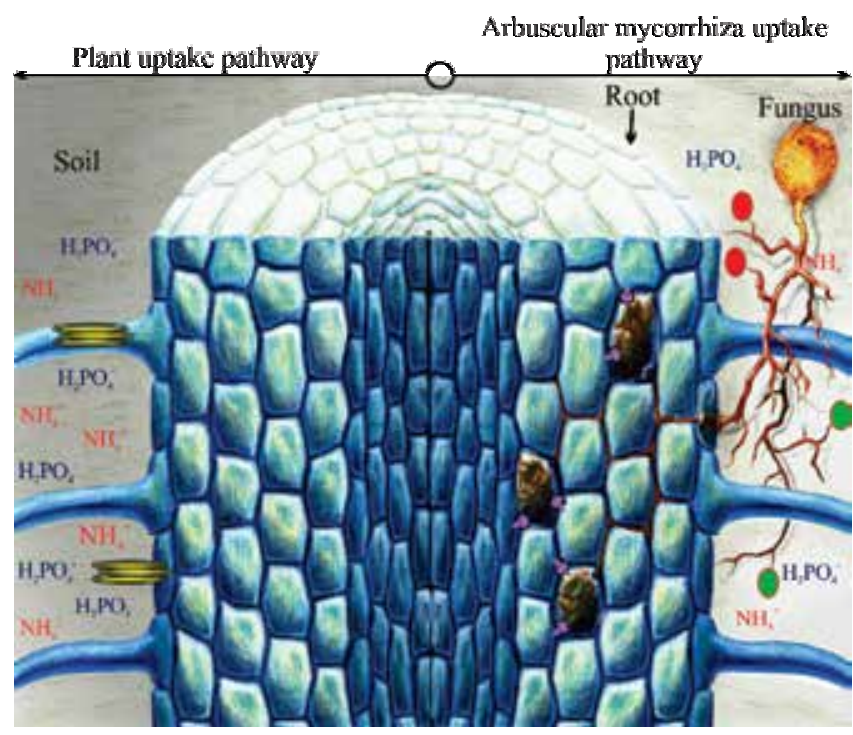

Figure 2. Plant and arbuscular mycorrhiza uptake pathways. Yellow symbols represent the transporters located in the epidermis and in the root hairs; red or green symbols, fungi transporters located in the extraradical mycelium; and purple symbols, plant transporters induced by the arbuscular mycorrhiza and that are located in the periarbuscular membrane. 
translocated to the intraradical mycelium and then released to the plant (Jakobsen et al., 1992; Yang et al., 2012). It was shown that the extraradical mycelium of mycorrhizae in carrot (Daucus carota L.) and Medicago truncatula Gaertn., both inoculated with the fungus Glomus intraradices (Syn. Rhizophagus intraradices), virtually exhausted $35 \mu \mathrm{mol} \mathrm{L} \mathrm{L}^{-1} \mathrm{H}_{2} \mathrm{PO}_{4}{ }^{-}$added to the liquid medium after four weeks (Maldonado-Mendoza et al., 2001). Subsequently, these authors added ${ }^{33}[\mathrm{P}]-$ orthophosphate to the medium and confirmed that, indeed, the extraradical mycelium absorbs the $\mathrm{H}_{2} \mathrm{PO}_{4}{ }^{-}$ ion and transfers it to the colonized roots.

After being absorbed, $\mathrm{H}_{2} \mathrm{PO}_{4}^{-}$is accumulated in the hyphae in tubular vacuoles (temporary storage and buffering of the $\mathrm{H}_{2} \mathrm{PO}_{4}^{-}$concentration) in the form of polyphosphate (PolyP-, a linear chain of $\mathrm{H}_{2} \mathrm{PO}_{4}^{-}$monomers, which can harbor thousands of orthophosphate ions), which is subsequently translocated along the hyphae (Olsson et al., 2010; Tisserant et al., 2012). The low concentration of $\mathrm{H}_{2} \mathrm{PO}_{4}{ }^{-}$ in the cytoplasm favors a greater absorption of this anion from the soil (Bapaume \& Reinhardt, 2012). $\mathrm{H}_{2} \mathrm{PO}_{4}^{-}$and PolyP- have negative charges that should be balanced by cations in the fungal cytoplasm (Smith $\&$ Smith, 2011); in the soil, $\mathrm{K}^{+}$and $\mathrm{Mg}^{2+}$ play this role (Ryan et al., 2007), but, in monoxenic cultures, with a high supply of sucrose and $\mathrm{N}$, arginine $\left(\mathrm{Arg}^{+}\right)$is suggested to translocate with PolyP- (Jin et al., 2005). The length of the PolyP- chain in the extraradical mycelium is greater than that in the intraradical one, suggesting that there is hydrolysis in the latter, which leads to a high concentration of $\mathrm{H}_{2} \mathrm{PO}_{4}^{-}$, facilitating its efflux, only slightly increased due to $\mathrm{C}$ supply (Solaiman et al., 1999; Solaiman \& Saito, 2001; Viereck et al., 2004).

\section{The $\mathrm{H}^{+}$-ATPase HA5 in AMF is induced by the arbuscular mycorrhiza}

Plasma membrane proton pumps ( $\mathrm{PM} \mathrm{H}^{+}$-ATPases) play a key role in the establishment of the $\mathrm{H}^{+}$ electrochemical gradient necessary for the transfer of nutrients across the plasmatic membranes of fungi and plants (Duby \& Boutry, 2009). An analysis of molecular data showed that most fungi have one to two genes that encode the $\mathrm{H}^{+}$-ATPases and that only one of these genes normally encodes $\mathrm{PM} \mathrm{H}^{+}$-ATPases (Requena et al., 2003; Balestrini et al., 2007). For example, brewer's yeast has two ATPase genes (Kerchove D'exaerde et al., 1996), while Uromyces viciae-fabae has only one (Struck et al., 1996). In the AMF Glomus mosseae, the first isoform of $\mathrm{H}^{+}-$ ATPases to be described was GmHA5 (Ferrol et al., 2000); subsequently, the gene that encodes the GmPMA1 isoform was identified (Requena et al., 2003). These $\mathrm{H}^{+}$-ATPase isoforms have a molecular mass of 105 and $100 \mathrm{kDa}$, respectively, and ten transmembrane helices, with the catalyst domain including the E1-E2 phosphorylation sites (Requena et al., 2003). The GmPMAl gene is expressed at high levels in the extraradical mycelium, especially during the nonsymbiotic growth phase, and at low levels during the symbiotic phase, with a reduction of about five-fold (Requena et al., 2003; Balestrini et al., 2007). The GmHA5 gene is little expressed during nonsymbiotic growth and is strongly induced in the symbiotic phase, 50 and 8-fold in the intra- and extraradical mycelia, respectively. A follow-up of the stages of intraradical mycelium development at 15, 20, 23 , and 28 days post-inoculation, with the respective expression of GmPMAl and GmHA5, showed that, although few fungal structures were observed at 15 days - basically only multiple appressoria in the epidermis -, the expression of GmHA5 was already clearly detectable (Requena et al., 2003). According to these authors, as the infection progressed, the expression levels of this gene increased and became similar to those of GmPMA1.

Next-generation sequencing has allowed the transcriptome analysis of the AMF genome and the quantification of transcript levels, which enables the confirmation or revision of previously obtained results, or even the targeting of new research. With this technology, for example, it was possible to identify the presence of the PM H $\mathrm{H}^{+}$-ATPase HA5 in the genome of Gigaspora margarita (Xie et al., 2016) and of other $\mathrm{H}^{+}$-ATPases in the genome of $G$. intraradices, which have not been fully characterized yet (Tisserant et al., 2012, 2013).

\section{The PM H'-ATPase of the plant, HA1, is induced by the arbuscular mycorrhiza}

The PM H $\mathrm{H}^{+}$-ATPase of the superfamily of P-type ATPases is the main proton pump of the plasmatic membrane of plants (Janicka-Russak, 2011). In many plant species, the PM $\mathrm{H}^{+}$-ATPase is encoded by a family of about 12 genes, subdivided into five subfamilies (Arango et al., 2003; Taiz et al., 2017). The genes MtHAl of M. truncatula, OsA8 (also 
known as OsHAl) of rice (Oryza sativa L.) (Arango et al., 2003; Sperandio et al., 2011), and SlHA8 of tomato (Solanum lycopersicum L.), included in subfamily $\mathrm{V}$, are the only orthologous $\mathrm{PM} \mathrm{H}^{+}$-ATPase genes exclusively expressed in root cells containing arbuscules (Krajinski et al., 2014; Wang et al., 2014; Liu et al., 2016). The first $\mathrm{PM} \mathrm{H}^{+}$-ATPase differentially expressed in response to mycorrhizal colonization was described in barley (Hordeum vulgare L.) (Murphy et al., 1997); soon after, two other PM $\mathrm{H}^{+}$-ATPases were identified in the arbuscular mycorrhiza of tobacco (Nicotiana tabacum L.) (Gianinazzi-Pearson et al., 2000). These PM H $\mathrm{H}^{+}$-ATPases contribute to the absorption of anions and other nutrients in the periarbuscular space, through an active process that occurs on symports with $\mathrm{H}^{+}$(Karandashov \& Bucher, 2005).

The expression of the HAl gene during the development of the arbuscular mycorrhiza promotes an adequate colonization of fungi, improves the absorption of $\mathrm{H}_{2} \mathrm{PO}_{4}^{-}$by the plant, and energizes the periarbuscular membrane (Wang et al., 2014). HA1 energizes the periarbuscular membrane of rice and M. truncatula to facilitate the transport of nutrients, such as $\mathrm{H}_{2} \mathrm{PO}_{4}^{-}$, most likely through the action of OsPT11 and MtPT4, which are $\mathrm{H}_{2} \mathrm{PO}_{4}^{-}$transporters of rice and M. truncatula, respectively (Wang et al., 2014; Volpe et al., 2016).

The period, between 28 and 35 days after inoculation, in which the genes MtHAl (exclusively expressed in cells containing arbuscules) and $O s H A 1$ are strongly induced, is consistent with the development time of the arbuscules (Wang et al., 2014), when the nutritional exchanges between the symbionts are more intense. Therefore, it is expected that the SIHAS gene - an orthologous of MtHAI and OsHAI - also be strongly induced in cells containing arbuscules and inactivated in plants not colonized by mycorrhizal fungi and cultivated under normal growth or nutrient or salt stress conditions (Liu et al., 2016).

As the MtPT4 and MtHAl genes are coexpressed, they can have associated functions. In fact, by reducing the levels of MtHAl expression, a reduction in the intake of the symbiotic phosphate by mutant plants is observed (Wang et al., 2014). In addition, the mutants mtpt4 and mthal-1 exhibit the same phenotype, especially a reduction in the level of colonization and a steep decline in the number of fully developed arbuscules (Javot et al., 2007; Wang et al., 2014).

In the arbuscular mycorrhiza, the activity of the $\mathrm{H}^{+}$ pump is extremely dependent on the $\mathrm{H}^{+}$-ATPase HA1, since neither the fungal $\mathrm{PM} \mathrm{H} \mathrm{H}^{+}$-ATPase nor any other $\mathrm{PM} \mathrm{H}^{+}$-ATPase of the plant can compensate for a mutant defective for the $H A l$ gene (Krajinski et al., 2014). If the levels of $H A 1$ transcripts are increased with the colonization of AMF, this gene is also responsible for the $\mathrm{H}^{+}$gradient (Krajinski et al., 2014), which makes the periarbuscular space more acid. It should be noted that the $\mathrm{H}^{+}$gradient is formed by the $\mathrm{PM} \mathrm{H}^{+}$-ATPases of the plant, the fungus, and the deprotonation processes of $\mathrm{NH}_{4}^{+}$(Guether et al., 2009).

\section{AMF $\mathrm{H}_{2} \mathrm{PO}_{4}^{-}$transporters induced by the arbuscular mycorrhiza}

$\mathrm{H}_{2} \mathrm{PO}_{4}^{-}$is essential for the growth and development of plants, but is often a limiting factor (Holford, 1997) because its concentration in the soil is low, only up to $10 \mu \mathrm{mol} \mathrm{L}^{-1}$ (Vance et al., 2003). Therefore, access to additional $\mathrm{H}_{2} \mathrm{PO}_{4}^{-}$transported by the arbuscular mycorrhiza has a significant effect on plant growth and development (Maldonado-Mendoza et al., 2001). Studies with radioisotopes have shown that the extraradical mycelium is responsible for the absorption of $\mathrm{H}_{2} \mathrm{PO}_{4}^{-}$, which is subsequently translocated to the intraradical mycelium and then released to the plant (Jakobsen et al., 1992).

$\mathrm{H}_{2} \mathrm{PO}_{4}^{-}$transporters coupled with $\mathrm{H}^{+}$were identified in the plasma membrane of AMF and in the periarbuscular membrane of the plant (Benedetto et al., 2005; Tisserant et al., 2012; Volpe et al., 2016). The $\mathrm{H}^{+}$gradient is known to energize the membrane for nutrient transport (Gaxiola et al., 2007). AMF have both a high-affinity system for the transport of $\mathrm{H}_{2} \mathrm{PO}_{4}{ }^{-}$, with $\mathrm{K}_{\mathrm{m}}$ between $1.8-3.1 \mu \mathrm{mol} \mathrm{L} \mathrm{L}^{-1}$, and a low-affinity one, with $\mathrm{K}_{\mathrm{m}}$ between $10.2-11.3 \mathrm{mmol} \mathrm{L}^{-1}$ (Thomson et al., 1990). GigmPT, for example, which acts as a highaffinity phosphorus transporter in the extraradical mycelium of $G$. margarita and in cells containing arbuscules, showed $\mathrm{K}_{\mathrm{m}}$ of $1.8 \pm 0.7 \mu \mathrm{mol} \mathrm{L}^{-1}$ (Xie et al., 2016).

From the AMF Glomus versiforme, a high-affinity $\mathrm{H}_{2} \mathrm{PO}_{4}^{-}$transporter, GvPT, with $\mathrm{K}_{\mathrm{m}}$ of $18 \mu \mathrm{mol} \mathrm{L}^{-1}$ (Harrison \& Van Buuren, 1995), was cloned, whose structure and sequences are similar to those of another high-affinity transporter that acts on symports with one $\mathrm{H}^{+}$from Saccharomyces cerevisiae, mediated by 
protein PHO84 (Bun-Ya et al., 1991; Tisserant et al., 2012), and from Neurospora crassa, by protein PHO5 (Versaw, 1995). At the amino acid level, GvPT shares $47.9 \%$ homology with PHO84 of S. cerevisiae, $45 \%$ with PHO-5 of $N$. crassa, and $95 \%$ with the high-affinity $\mathrm{H}_{2} \mathrm{PO}_{4}^{-}$transporter GiPT of the extraand intraradical mycelia of G. intraradices (Harrison \& Van Buuren, 1995; Maldonado-Mendoza et al., 2001; Tisserant et al., 2012; Fiorilli et al., 2013). GiPT shares $73 \%$ homology with the high-affinity $\mathrm{H}_{2} \mathrm{PO}_{4}^{-}$transporter GmosPT, present in the intraand extraradical mycelia of $G$. mosseae, which also acts on symports with one $\mathrm{H}^{+}$(Benedetto et al., 2005; Balestrini et al., 2007). GvPT, GiPT, and GmosPT absorb $\mathrm{H}_{2} \mathrm{PO}_{4}^{-}$from the soil, show high similarity, and are phylogenetically grouped to fungal transporters, which are separated from the group of plant transporters (Harrison \& Van Buuren, 1995; Maldonado-Mendoza et al., 2001; Benedetto et al., 2005). GmosPT and GvPT are induced in the extraradical mycelium by micromolar concentrations of $\mathrm{H}_{2} \mathrm{PO}_{4}^{-}$(Maldonado-Mendoza et al., 2001; Benedetto et al., 2005). GmosPT presented similar levels of expression in the extra- and intraradical mycelia; therefore, it has been suggested that it could control the efflux of $\mathrm{H}_{2} \mathrm{PO}_{4}^{-}$in the periarbuscular space through the partial resorption of this nutrient (Benedetto et al., 2005; Balestrini \& Lanfranco, 2006). The resorption of $\mathrm{H}_{2} \mathrm{PO}_{4}^{-}$in the periarbuscular space has also been attributed to GimPT, since its inactivation retards the growth of $G$. margarita and hinders the development of its arbuscules (Xie et al., 2016), which suggests that the $\mathrm{P}$ metabolism in the arbuscules may rely solely on the $\mathrm{H}_{2} \mathrm{PO}_{4}{ }^{-}$absorbed by this transporter.

Glomus intraradices is able to perceive and respond to the levels of $\mathrm{H}_{2} \mathrm{PO}_{4}^{-}$that surround its extraradical mycelium (Maldonado-Mendoza et al., 2001). The GiPT gene is expressed in the extraradical mycelium in response to low- $\mathrm{H}_{2} \mathrm{PO}_{4}^{-}$conditions in the environment that surround this mycelium and to the status of $\mathrm{H}_{2} \mathrm{PO}_{4}^{-}$in the arbuscular mycorrhiza (Maldonado-Mendoza et al., 2001). These authors detected increases of GiPT transcripts, accompanied by a reduction in $\mathrm{H}_{2} \mathrm{PO}_{4}^{-}$concentration, when the extraradical mycelium of the arbuscular mycorrhiza of $G$. intraradices, in carrot, was exposed to 1.0 , 5.0, 10, 20, and $35 \mu \mathrm{mol} \mathrm{L} \mathrm{L}^{-1} \mathrm{H}_{2} \mathrm{PO}_{4}^{-}$, but not to 0.0 or $3.5 \mathrm{mmol} \mathrm{L}^{-1}$, indicating that this transporter operates when $\mathrm{H}_{2} \mathrm{PO}_{4}{ }^{-}$concentration in the external environment is low. In addition, they observed that, by providing $3.5 \mathrm{mmol} \mathrm{L}^{-1} \mathrm{H}_{2} \mathrm{PO}_{4}^{-}$to this same mycorrhiza and supplementing the extraradical mycelium with $35 \mu \mathrm{mol} \mathrm{L} \mathrm{L}^{-1} \mathrm{H}_{2} \mathrm{PO}_{4}^{-} 48$ hours after incubation, the final concentration in this mycelium, after another 48 hours, was $40 \mu \mathrm{mol} \mathrm{L}^{-1}$, which shows that $\mathrm{H}_{2} \mathrm{PO}_{4}^{-}$was not absorbed. It should be pointed out that the molecular mechanisms that promote the efflux of $\mathrm{H}_{2} \mathrm{PO}_{4}^{-}$in the intraradical mycelium, i.e., in the fungal structures that are present on the root surface, are not yet well known (Smith \& Smith, 2011; Tisserant et al., 2012; Bücking \& Kafle, 2015).

\section{$\mathrm{N}$ absorption through the extraradical mycelium and arbuscule of AMF}

\section{Kinetics of $\mathrm{NH}_{4}{ }^{+}$absorption}

The absorption of $\mathrm{NH}_{4}^{+}$by the extraradical mycelium of $G$. intraradices is mediated by the lowand high-affinity transport systems (Pérez-Tienda et al., 2012). These two systems are dependent on the metabolic energy and the electrochemical gradient of $\mathrm{H}^{+}$generated by PM H $\mathrm{H}^{+}$-ATPases (Ferrol et al., 2000; Requena et al., 2003; Pérez-Tienda et al., 2012). In fact, the high-affinity transport system and, to some extent, the low-affinity one were inhibited by carbonyl cyanide m-chlorophenyl hydrazone (CCCP) and by the inhibitor of adenosine triphosphate (ATP) synthesis, 2,4-dinitrophenol (2,4-DNP) (Pérez-Tienda et al., 2012). Similar inhibitory effects of CCCP and 2,4DNP were observed on the absorption of $\mathrm{NH}_{4}{ }^{+}$in other fungi, such as Paxillus involutus (Javelle et al., 1999).

At concentrations lower than $1.0 \mathrm{mmol} \mathrm{L}^{-1} \mathrm{NH}_{4}^{+}$, the absorption of ammonium is mediated by the saturable high-affinity transport system, with $\mathrm{K}_{\mathrm{m}}$ of $2.53 \pm 0.25 \mu \mathrm{mol} \mathrm{L} \mathrm{L}^{-1}$, indicating that the extraradical mycelium can absorb enough quantities of $\mathrm{N}$ from the soil even at very low concentrations of the nutrient (Pérez-Tienda et al., 2012). The high-affinity transport system for $\mathrm{NH}_{4}{ }^{+}$has been reported in other fungi, such as: for Laccaria bicolor (Jongbloed et al., 1991), with $\mathrm{K}_{\mathrm{m}}$ of $6.0 \mu \mathrm{mol} \mathrm{L}-1$; for $S$. cerevisiae, with $\mathrm{K}_{\mathrm{m}}$ of 1.0-10 $\mu \mathrm{mol} \mathrm{L}{ }^{-1}$ (Marini et al., 1994, 1997); and for Agaricus bisporus, with $\mathrm{K}_{\mathrm{m}}$ of $3.7 \mu \mathrm{mol} \mathrm{L} \mathrm{L}^{-1}$ (Kersten et al., 1999). It should be highlighted that the high-affinity transport system of $G$. intraradices has five-fold greater affinity for $\mathrm{NH}_{4}{ }^{+}$than that of plants, 
which would enable AMF to absorb the $\mathrm{NH}_{4}{ }^{+}$from the soil even at low concentrations (Pérez-Tienda et al., 2012). $K_{m}$ values of the high-affinity transport system for $\mathrm{NH}_{4}^{+}$are typically higher in plants than in fungi (Howitt \& Udvardi, 2000; D’apuzzo et al., 2004; PérezTienda et al., 2012). In the high-affinity transport system, there is certainly a contribution of GintAMT1, a high-affinity $\mathrm{NH}_{4}{ }^{+}$transporter of the extraradical mycelium of $G$. intraradices, since its apparent $\mathrm{K}_{\mathrm{m}}$ is of $26 \mu \mathrm{mol} \mathrm{L}{ }^{-1}$ and dependent on the ATPase activity, typical of a high-affinity $\mathrm{NH}_{4}^{+}$transporter. At concentrations higher than $1.0 \mathrm{mmol} \mathrm{L}^{-1}$, the absorption rate of the extraradical mycelium of $G$. intraradices is directly proportional to the concentrations of ${ }^{15} \mathrm{NH}_{4}^{+}$ in the external environment, indicating the action of the nonsaturable low-affinity transport system, whose first discovered representative is GintAMT3, also of G. intraradices (Calabrese et al., 2016).

\section{AMF $\mathrm{NH}_{4}{ }^{+}$transporters inducible by arbuscular mycorrhiza}

AMF can absorb and transport large amounts of $\mathrm{N}$ to plants (Jin et al., 2005). In G. intraradices, three genes of $\mathrm{NH}_{4}^{+}$transporters (AMTs), GintAMT1 (López-Pedrosa et al., 2006), GintAMT2 (PérezTienda et al., 2011), and GintAMT3 (Calabrese et al., 2016), have already been cloned and characterized. All of these genes encode a polypeptide chain of 479, 471, and 454 amino acid residues, respectively, with 11 transmembrane domains (López-Pedrosa et al., 2006; Pérez-Tienda et al., 2011; Calabrese et al., 2016). GintAMT1 and GintAMT2 share a high homology with AMTs of other previously characterized fungi and have 50-kDa molecular mass (López-Pedrosa et al., 2006; Pérez-Tienda et al., 2011). GintAMT2 is a paralog of GintAMT3 (Calabrese et al., 2016) and shows a high similarity with functionally characterized AMTs, such as GintAMT1 of $G$. intraradices (López-Pedrosa et al., 2006) and HcAMT1 and TbAMT1 of the ECM Hebeloma cylindrosporum (Javelle et al., 2001) and Tuber borchii, respectively (Montanini et al., 2002). The heterologous expression of GintAMT1, GinAMT2, and GintAMT3 in mutant yeast - defective in the ammonium permeases MEP1, MEP2, and MEP3, respectively - complements the defect of the strain to grown in the presence of less than $1.0 \mathrm{mmol} \mathrm{L}^{-1} \mathrm{NH}_{4}^{+}$, which indicates that these are three genes of functional transporters of $\mathrm{NH}_{4}{ }^{+}$(López-Pedrosa et al., 2006; PérezTienda et al., 2011; Calabrese et al., 2016). GintAMT1 is induced by $\mathrm{NH}_{4}^{+}$and preferably expressed in the extraradical mycelium (López-Pedrosa et al., 2006; Pérez-Tienda et al., 2011). GintAMT1 and GintAMT2 are high-affinity transporters involved in the absorption of $\mathrm{NH}_{4}{ }^{+}$at low concentrations (López-Pedrosa et al., 2006; Pérez-Tienda et al., 2011). However, unlike GintAMT1, GintAMT2 is preferentially expressed in the intraradical mycelium and is not induced by its substrate. These two transporters are expressed in cells containing arbuscules (Pérez-Tienda et al., 2011), which indicates that they can control the efflux of $\mathrm{N}$ in the periarbuscular space through the absorption of this element (Bapaume \& Reinhardt, 2012). GintAMT3, located in the plasma and vacuolar membrane, is a low-affinity transporter that is more expressed in the intraradical mycelium than in the extraradical one (Calabrese et al., 2016), which confirms that the absorption of $\mathrm{NH}_{4}{ }^{+}$by the extraradical mycelium of $G$. intraradices is also mediated by the low-affinity system (Pérez-Tienda et al., 2012). The presence of this transporter in the intraradical mycelium suggests that AMF can provide a mechanism for the removal of any excess $\mathrm{NH}_{4}^{+}$accumulated in the periarbuscular space and can compartmentalize it in structures such as vacuoles, neutralizing a possible phytotoxic effect of this nutrient in the host plant.

\section{AMF $\mathrm{NO}_{3}^{-}$transporters responsive to arbuscular mycorrhiza}

Although AMF absorb $\mathrm{NO}_{3}{ }^{-}$and $\mathrm{NH}_{4}{ }^{+}$, there is a clear preference for the latter, which can be partially explained by the fact that part of the energy of the fungus is dissipated during the reduction of $\mathrm{NO}_{3}{ }^{-}$to $\mathrm{NH}_{4}{ }^{+}$prior to the nutrient's incorporation into organic compounds (Marzluf, 1996; Gachomo et al., 2009); excess $\mathrm{NH}_{4}^{+}$is toxic, unless it is quickly assimilated into these compounds (Temple et al., 1998).

The $\mathrm{NO}_{3}{ }^{-}$transporters (NRTs) of AMF have not been fully characterized, but transcriptome studies have shown the existence of several of these transporters in the spore and in the extra- and intraradical mycelia of the AMF G. intraradices (Tisserant et al., 2012, 2013). A probable high-affinity transporter of this fungus, GiNT, is induced by the supply of $\mathrm{NO}_{3}{ }^{-}$in the extraradical mycelium (Tian et al., 2010; Koegel et al., 2015).

Based on changes in $\mathrm{pH}$ caused by the extraradical mycelium when the hyphae are supplemented with $\mathrm{NO}_{3}{ }^{-}$or $\mathrm{NH}_{4}^{+}$, it has been suggested that the uptake 
of $\mathrm{NO}_{3}{ }^{-}$by the hyphae is an active process that occurs on symports with $\mathrm{H}^{+}$, while the absorption of $\mathrm{NH}_{4}^{+}$ operates on antiports with $\mathrm{H}^{+}$efflux (Bago et al., 1996).

\section{Nitrogen assimilation and transport by AMF}

\section{Reduction of $\mathrm{NO}_{3}{ }^{-}$in $\mathrm{AMF}$}

After absorption by the plant or fungus, $\mathrm{NO}_{3}^{-}$is reduced by nitrate reductase to $\mathrm{NO}_{2}{ }^{-}$. Transcriptome studies have shown the existence of several NRTs in spores and in the extra- and intraradical mycelia of G. intraradices (Tisserant et al., 2012, 2013). The genes GiNR1 and GiNR2, which encode nitrate reductase, are induced in the extraradical mycelium in the arbuscular mycorrhiza of G. intraradices on sorghum [Sorghum bicolor (L.) Moench] under $\mathrm{N}$ deprivation or urea supplementation (Koegel et al., 2015). These same genes, plus GiNR3, are also induced in the intraradical mycelium when the extraradical one is supplied with glycine as the sole N source (Tian et al., 2010; Koegel et al., 2015), which suggests that the nitrate reductase of AMF can also act in a complementary way in the $\mathrm{N}$ nutrition of the host plant, reducing the $\mathrm{NO}_{3}{ }^{-}$ remobilized from vacuoles to provide more $\mathrm{NH}_{4}{ }^{+}$to the plant.

Fungi preferably use nicotinamide adenine dinucleotide phosphate (NADPH) as a reducing agent for the formation of $\mathrm{NO}_{2}^{-}$(Kaldorf et al., 1998; Tisserant et al., 2013). For example, the formation of $\mathrm{NO}_{2}^{-}$catalyzed by nitrate reductase was mainly NADPH-dependent in the roots of plants colonized by AMF, but not in the control (Kaldorf et al., 1998). Nitrate reductase activity in the roots (Subramanian \& Charest, 1998; Hawkins \& George, 1999; Rani et al., 2017) and shoots (Faure et al., 1998; Hajong et al., 2013; Rani et al., 2017) of the plants colonized by AMF is generally greater than that in the uncolonized control. In plants not colonized by $\mathrm{AMF}, \mathrm{NO}_{3}{ }^{-}$reduction occurs predominantly in leaves, and, in the colonized ones, in roots (Kaldorf et al., 1998; Vázquez et al., 2001).

\section{Reduction of $\mathrm{NO}_{2}^{-}$in $\mathrm{AMF}$}

The second stage of $\mathrm{N}$ assimilation is the conversion of $\mathrm{NO}_{2}{ }^{-}$to $\mathrm{NH}_{4}{ }^{+}$by nitrite reductase. A gene that encodes for nitrite reductase of the AMF $G$. intraradices, predicted by a software, shows the expression of this enzyme in spores and in extra- and intraradical mycelia (Tisserant et al., 2012, 2013). The expression of $T b N i R l$, a gene that encodes nitrite reductase in the
ECM T. borchii, is induced by $\mathrm{NO}_{3}^{-}$, but it is repressed when the most preferred sources of $\mathrm{N}$, such as $\mathrm{NH}_{4}{ }^{+}$ or glutamine, become available (Guescini et al., 2007).

The activity of nitrite reductase in ECM controls the expression of the gene that encodes the enzyme in the plant. The expression of nitrite reductase in the plant is repressed when its roots are colonized by the wild-type fungus, but increases when they are colonized by the fungus with this defective enzyme (Bailly et al., 2007). In fact, in the roots of plants colonized by mycorrhizal fungi, the levels of nitrite reductase transcripts are lower than those in the ones of the uncolonized control (Kaldorf et al., 1998; Hildebrandt et al., 2002), which suggests that the expression of this enzyme in the plant is suppressed by the transfer of reduced $\mathrm{N}$ compounds from the fungus to the host plant (Bailly et al., 2007).

\section{Assimilation of $\mathbf{N}$ in carbon skeletons of AMF}

Usually, the $\mathrm{NH}_{4}^{+}$absorbed by the extraradical mycelium is assimilated by the glutamine synthetaseglutamate synthase pathway (GS-GOGAT) (Koegel et al., 2015). In this pathway, glutamine is produced from glutamate and $\mathrm{NH}_{4}^{+}$by glutamine synthetase; then, glutamine and 2-oxoglutarate are converted by glutamate synthase (also known as glutamine 2-oxoglutarate aminotransferase) into two molecules of glutamate (Tian et al., 2010; Fellbaum et al., 2012).

Two different functional isoforms of GS, GiGS1 and GiGS2, and one of GOGAT, GiGluS, from $G$. intraradices (Tian et al., 2010; Koegel et al., 2015), have been identified. GiGS1 has a lower $K_{m}$ than GiGS2 and is constitutively expressed at high levels in the extraradical mycelium, while GiGS2 is strongly induced by the addition of $\mathrm{NO}_{3}{ }^{-}$to the same mycelium, which indicates that GiGS1 is the main functional enzyme for $\mathrm{N}$ assimilation at low concentrations and that GiGS2 can play a more significant role in the nutrient's assimilation in high-supply conditions (Gomez et al., 2009; Tian et al., 2010; Koegel et al., 2015). Regardless of the N source, GiGluS is more expressed in the extraradical mycelium than in the intraradical one (Tian et al., 2010; Koegel et al., 2015). As observed in the GS-GOGAT pathway, glutamine becomes strongly labeled when $\mathrm{NH}_{4}{ }^{+}{ }^{15} \mathrm{~N}$ is supplied to AMF and represents one of the largest drains of $\mathrm{N}$ (Cliquet \& Stewart, 1993; Jin et al., 2005; Gachomo et al., 2009). Glutamine plays a central role in the metabolism of $\mathrm{N}$, by donating this nutrient, a precursor to many essential metabolites, such as nucleic acids

Pesq. agropec. bras., Brasília, v.54, e25140, 2019

DOI: 10.1590/S1678-3921.pab2019.v54.25140 
and amino acids (histidine, tyrosine, and asparagine, for example), and by regulating the involved genes (Marzluf, 1996; Javelle et al., 2003; Navarro et al., 2006). Due to these important functions, the levels of free glutamine in AMF are tightly controlled (Gachomo et al., 2009).

\section{Transport of $\mathbf{N}$ from the extraradical to the intraradical mycelium}

The $\mathrm{N}$ absorbed by the extraradical mycelium is quickly transformed into amino acids, particularly arginine, which is accumulated at high concentrations in this mycelium (Govindarajulu et al., 2005; Cruz et al., 2007; Tian et al., 2010). The assimilation of $\mathrm{NO}_{3}{ }^{-}$ (Govindarajulu et al., 2005; Tian et al., 2010) or $\mathrm{NH}_{4}^{+}$ labelled with ${ }^{15} \mathrm{~N}$ (Govindarajulu et al., 2005; Cruz et al., 2007) showed that arginine is the main form of $\mathrm{N}$ transported from the extraradical mycelium to the intraradical one. Higher concentrations of arginine were observed in the extraradical mycelium than in the tissues of roots both colonized and not colonized with AMF (Jin et al., 2005). Arginine is the most abundant free amino acid and can represent more than $90 \%$ of them in the extraradical mycelium (Calabrese et al., 2016). In addition, arginine levels above $200 \mathrm{nmol}$ $\mathrm{L}^{-1} \mathrm{mg}^{-1}$ dry weight were reported in this mycelium (Jin et al., 2005). Due to the low C/N ratio (6:4), arginine plays an important role in the storage and transfer of $\mathrm{N}$ from the extraradical mycelium to the intraradical one (Govindarajulu et al., 2005; Jin et al., 2005; Cruz et al., 2007).

In the intraradical mycelium, the cleavage of arginine occurs through the catabolic pathway of the urea cycle, which releases $\mathrm{NH}_{4}{ }^{+}$and the carbon skeleton (Cruz et al., 2007; Tian et al., 2010; Tisserant et al., 2012; Koegel et al., 2015). While the carbon skeleton is retained in the fungus, $\mathrm{NH}_{4}{ }^{+}$is transferred to the cells of the host plant. Therefore, the amino acids of colonized-root proteins were not detectably labelled with ${ }^{13} \mathrm{C}$ even when large amounts of $\mathrm{N}$ were transferred from the fungus to the plant, which shows that the amino acids were translocated to the intraradical mycelium and hydrolyzed, and that inorganic $\mathrm{N}$ was transferred to the periarbuscular space (Govindarajulu et al., 2005). Moreover, the strong labeling by ${ }^{15} \mathrm{~N}$ in free amino acids and in those obtained by the hydrolysis of colonizedroot proteins shows the translocation and transfer of $\mathrm{N}$ from the extraradical mycelium to the cells of the host plant (Govindarajulu et al., 2005).
Gene expression studies are consistent regarding the biosynthesis of arginine in the extraradical mycelium. Soon after the supply of $\mathrm{NO}_{3}{ }^{-}$or other $\mathrm{N}$ sources, the transcript levels of carbamoyl phosphate synthetase (CPS), argininosuccinate synthase (ASS), and argininosuccinate lyase (AL) are induced in this mycelium (Tian et al., 2010; Fellbaum et al., 2012; Tisserant et al., 2012; Koegel et al., 2015); all these enzymes are involved in the biosynthesis of arginine. CPS catalyzes the formation of carbamoyl phosphate from $\mathrm{CO}_{2}$, adenosine triphosphate (ATP), and $\mathrm{NH}_{3}$, which, together with ornithine (synthesized from glutamate), are converted to citrulline and $\mathrm{H}_{2} \mathrm{PO}_{4}^{-}$ by ornithine transcarbamylase (Cruz et al., 2007; Tian et al., 2010; Tisserant et al., 2012; Koegel et al., 2015). ASS converts citrulline and aspartate into argininosuccinate, and AL into fumarate and arginine (Jennings, 1995; Tian et al., 2010; Tisserant et al., 2012). In contrast, in the intraradical mycelium, arginase, urease (which hydrolyses urea to $\mathrm{NH}_{4}^{+}$and $\mathrm{CO}_{2}$ ), and ornithine aminotransferase, coded by the genes CARl, $U R E$, and $O A T$, are strongly induced to participate in the catabolism of arginine (Cruz et al., 2007; Tian et al., 2010; Tisserant et al., 2012; Koegel et al., 2015). The biosynthesis of arginine in the extraradical mycelium and the subsequent hydrolysis of this amino acid in the intraradical mycelium are spatially separated, but synchronized processes that occur in AMF through the anabolic and catabolic pathways of the urea cycle, respectively (Cruz et al., 2007; Tian et al., 2010). The synchronization of these processes suggests that arginine plays an important role in the translocation of $\mathrm{N}$ from the extraradical mycelium to the intraradical one (Govindarajulu et al., 2005; Jin et al., 2005; Cruz et al., 2007; Tian et al., 2010).

Both the host plant and AMF can monitor and discriminate which one of their several partners is more active for nutritional exchanges, rewarding it with more $\mathrm{C}$ or mineral nutrients (Bücking \& ShacharHill, 2005; Hammer et al., 2011; Kiers et al., 2011; Fellbaum et al., 2012, 2014). An increase in C supply by the plant leads to a greater induction of the genes involved in $\mathrm{N}$ assimilation (e.g., GluS, GS1, and GS2) and in the biosynthesis of arginine (e.g., CPS, ASS, and $A L$ ), but to a low induction of URE, CARl, and NRTs in the extraradical mycelium (Fellbaum et al., 2012, 2014), which reduces the catabolism and stimulates the biosynthesis and the transfer of arginine 
from the extraradical mycelium to the intraradical one. In the intraradical mycelium, there is a greater induction of URE, CAR1, OAT1, and OAT2 and a low induction of the genes involved in the biosynthesis of arginine, which favors the catabolism of arginine and prevents the reassimilation of the $\mathrm{NH}_{4}{ }^{+}$released in this mycelium (Cruz et al., 2007; Tian et al., 2010; Fellbaum et al., 2012; Koegel et al., 2015). This shows that the host plant is able to regulate the gene expression of the fungus with the provision of $\mathrm{C}$ and to stimulate the transport of $\mathrm{N}$ towards the periarbuscular space (Fellbaum et al., 2012).

AMF regulate the transport of nutrients to the host plant by the accumulation and remobilization of PolyP- and arginine in the intraradical mycelium and by the amount of $\mathrm{C}$ offered by the host plant, which can reduce or stimulate, in conditions of low or high $\mathrm{C}$ supply, respectively, the cleavage of PolyP- and arginine to release $\mathrm{H}_{2} \mathrm{PO}_{4}{ }^{-}$and $\mathrm{NH}_{4}{ }^{+}$into the periarbuscular space (Bücking \& Heyser, 2003; Bücking \& Shachar-Hill, 2005; Kiers et al., 2011; Fellbaum et al., 2012).

Figure 3 shows a model for the absorption of $\mathrm{N}$ and $\mathrm{P}$ by $\mathrm{AMF}$, including their transport and release into the periarbuscular space and their association with $\mathrm{C}$. The extraradical mycelium absorbs inorganic $\mathrm{P}$ and $\mathrm{N}$ by the $\mathrm{H}_{2} \mathrm{PO}_{4}^{-}, \mathrm{NH}_{4}^{+}$, and $\mathrm{NO}_{3}{ }^{-}$transporters energized by the $\mathrm{PM} \mathrm{H}^{+}$-ATPases. $\mathrm{N}$ is assimilated and concentrated mainly in the form of arginine via GS-GOGAT,

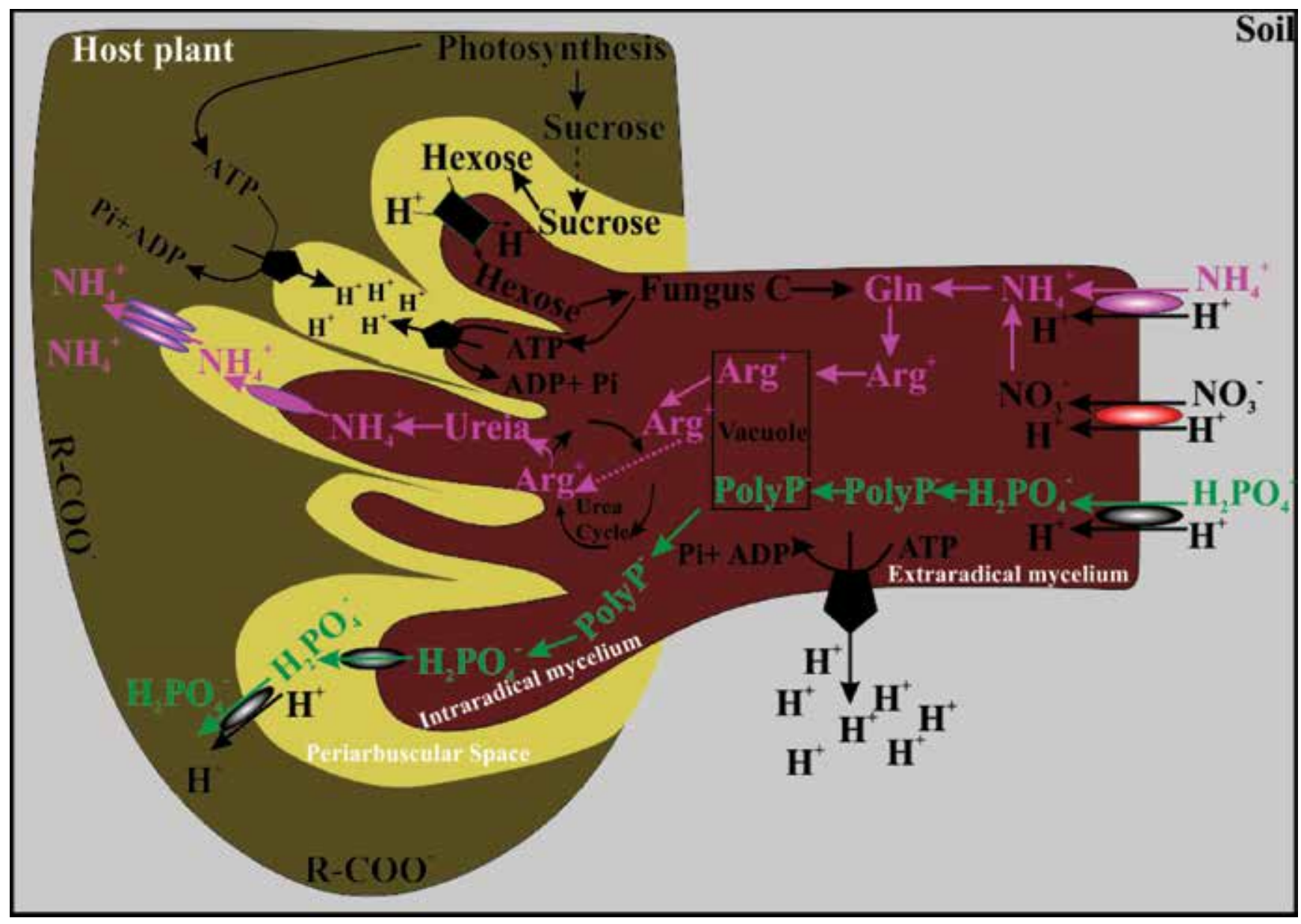

Figure 3. Model of $\mathrm{N}$ and $\mathrm{P}$ transport by the arbuscular mycorrhizal fungus uptake pathway. It emphasizes the absorption of $\mathrm{P}$ and $\mathrm{N}$ by the extraradical mycelium through the $\mathrm{H}_{2} \mathrm{PO}_{4}^{-}$(black), $\mathrm{NO}_{3}^{-}$(red), or $\mathrm{NH}_{4}^{+}$(pink) transporters; the assimilation and concentration of $\mathrm{N}$ within arginine $\left(\mathrm{Arg}^{+}\right)$and the conversion of $\mathrm{H}_{2} \mathrm{PO}_{4}^{-}$to polyphosphate (PolyP); the transfer of $\mathrm{Arg}^{+}$ and PolyP- from the extraradical to the intraradical mycelium; the breakdown of $\mathrm{Arg}^{+}$through the catabolic pathway of the urea cycle and of PolyP- into $\mathrm{NH}_{4}^{+}$and $\mathrm{H}_{2} \mathrm{PO}_{4}^{-}$, respectively, in the intraradical mycelium; $\mathrm{H}_{2} \mathrm{PO}_{4}^{-}$(green) and NH${ }_{4}^{+}$(pink) effluxes to the periarbuscular space; and the subsequent uptake of $\mathrm{H}_{2} \mathrm{PO}_{4}{ }^{-}$and $\mathrm{NH}_{4}{ }^{+}$by the host plant through the $\mathrm{H}_{2} \mathrm{PO}_{4}{ }^{-}$and $\mathrm{NH}_{4}{ }^{+}$transporters located in the periarbuscular membrane of the plant.. 
asparagine synthetase, and the anabolic pathway of the urea cycle, whereas $\mathrm{H}_{2} \mathrm{PO}_{4}^{-}$is converted into PolyP- in the extraradical mycelium. In this mycelium, arginine is transported to the fungal vacuole, where it binds to PolyP-, which, together with the amino acid, is transported to the intraradical mycelium. In this mycelium, arginine, through the catabolic route of the urea cycle, and $\mathrm{PolyP}^{-}$are hydrolyzed to release $\mathrm{NH}_{4}^{+}$and $\mathrm{H}_{2} \mathrm{PO}_{4}^{-}$. Effluxes of $\mathrm{H}_{2} \mathrm{PO}_{4}^{-}$and $\mathrm{NH}_{4}{ }^{+}$are directed towards the periarbuscular space, from where the host plant absorbs $\mathrm{P}$ and $\mathrm{N}$ through $\mathrm{H}_{2} \mathrm{PO}_{4}{ }^{-}$and $\mathrm{NH}_{4}^{+}$transporters and $\mathrm{H}^{+}$-ATPases located in the periarbuscular membrane and inducible by arbuscular mycorrhiza. The absorbed $\mathrm{P}$ and $\mathrm{N}$ stimulate photosynthesis and the release of sucrose towards the periarbuscular space, where the hydrolysis of sucrose occurs through the acidic invertases of the host plant and the absorption of hexoses by the monosaccharide transporters located in the plasma membrane of the intraradical mycelium.

\section{Transport of $\mathbf{N}$ and $\mathbf{P}$ from the periarbuscular space to the plant}

\section{Plant $\mathrm{NH}_{4}^{+}$transporters induced by arbuscular mycorrhiza}

The arbuscular mycorrhiza induces the expression of some plant AMTs, such as: LjAMT2;2 in Lotus japonicus (Regel) K.Larsen (Guether et al., 2009); GmAMT1.4, GmAMT3.1, GmAMT4.1 (more strongly induced), GmAMT4.3, and GmAMT4.4 in soybean [Glycine $\max$ (L.) Merr.] (Kobae et al., 2010); and OsAMT3.1 in rice (Pérez-Tienda et al., 2014) and its homologs, SbAMT3;1 and SbAMT4, in sorghum (Koegel et al., 2013). Four members (NPF2.2/PTR2, NPF1.3, NPF6.4, and NPF4.12) of the family of $\mathrm{NO}_{3}{ }^{-} /$peptide transporters that transport $\mathrm{NO}_{3}^{-}, \mathrm{NO}_{2}^{-}$ , peptides, amino acids, and phytohormones (auxins and abscisic and jasmonic acids) are also induced by arbuscular mycorrhiza (Drechsler et al., 2018).

The genes LjAMT2;2, orthologous to GmAMT4.1, and $S b A M T 3 ; 1$, orthologous to OsAMT3.1, which belong to the subfamilies AMT2 and AMT3, respectively, encode high-affinity AMTs and are located in cells containing arbuscules (Guether et al., 2009; Kobae et al., 2010; Koegel et al., 2013). Since GmAMT4.1 is located in branch regions of the periarbuscular membrane and not in the trunk region of the arbuscule, the transfer of $\mathrm{NH}_{4}{ }^{+}$occurs, in fact, in the arbuscule branch regions (Kobae et al., 2010). The heterologous expression of LjAMT2;2, GmAMT4.1, SbAMT3;1, and SbAMT4 in mutant yeast (defective in MEP1, MEP2, and MEP3) complements the defect of the strain to grow in the presence of 3.0, 1.5, and $1.0 \mathrm{mmol} \mathrm{L}^{-1} \mathrm{NH}_{4}^{+}$, respectively, indicating that these are genes of functional transporters of $\mathrm{NH}_{4}{ }^{+}$(Guether et al., 2009; Kobae et al., 2010; Koegel et al., 2013). The AMT LjAMT2;2 is pH-dependent - with high absorption rates at an acidic $\mathrm{pH}-$, recruits $\mathrm{NH}_{4}{ }^{+}$in the periarbuscular space and deprotonates it (removes a proton) before its transport through the membrane, and frees $\mathrm{NH}_{3}$ in the plant cytoplasm (Guether et al., 2009; Lamoureux et al., 2010).

Recently, two AMTs of M. truncatula, AMT2;3 and AMT2;4, wereidentified as having a rolein the arbuscule cycle (Breuillin-Sessoms et al., 2015). According to these authors, arbuscules are prematurely degraded in mtpt4 mutants, where PT4 - a mycorrhiza-inducible transporter of plant $\mathrm{H}_{2} \mathrm{PO}_{4}^{-}$- is not expressed, which is critical for the absorption of $\mathrm{H}_{2} \mathrm{PO}_{4}{ }^{-}$in the apoplastic interface. When the plant is grown under $\mathrm{N}$ stress, this premature degradation of arbuscules is suppressed by the expression of AMT2;3, but not by that of AMT2;4. However, only AMT2;4 was a functional transporter, as it facilitated the growth of mutant yeast in the yeast complementation test (Breuillin-Sessoms et al., 2015). This suggests that AMT2;3 and AMT2;4 differ regarding their function and that AMT2;3 could play a more sensitive or signaling role that the other AMTs do not have (Breuillin-Sessoms et al., 2015). It has been suggested that some mycorrhiza-inducible nutrient transporters located in the periarbuscular membrane could also act as transceptors (Xie et al., 2013).

\section{The $\mathrm{H}_{2} \mathrm{PO}_{4}^{-}$transporter of the plant, $\mathrm{PT} 4$, is induced by arbuscular mycorrhiza}

Arbuscular mycorrhiza induce the expression of some plant transporters such as MtPT4 (Javot et al., 2007) in M. truncatula, OsPT11 in rice (Paszkowski et al., 2002), and AsPT1 in Astragalus sinicus L. (Xie et al., 2013). These transporters are located in a specific domain of the periarbuscular membrane and allow the plant access to the $\mathrm{H}_{2} \mathrm{PO}_{4}{ }^{-}$absorbed by the extraradical mycelium, using the energy of the electrochemical potential gradient generated by $\mathrm{H}^{+}$-ATPases (Krajinski et al., 2014; Wang et al., 2014). MtPT4 shows a high transport activity of $\mathrm{H}_{2} \mathrm{PO}_{4}^{-}$in acidic conditions (Harrison et al., 2002), being considered a $\mathrm{H}_{2} \mathrm{PO}_{4}^{-}$ 
transporter of the PHT1 family, inducible by arbuscular mycorrhiza (Harrison et al., 2002; Volpe et al., 2016), just like LjPT4, a transporter found in L. japonicus (Volpe et al., 2013). The fusion of the promoter of the gene LjPT4 with UidA - a reporter gene that encodes the fluorescent enzyme $\beta$-glucuronidase (GUS) -, showed that GUS activity was concentrated in cells containing arbuscules, confirming that the LjPT4 transporter is inducible by arbuscular mycorrhiza (Volpe et al., 2016). LjTP4 is essential for the development of functional symbiosis and facilitates the transfer of phosphate from the fungus to the plant (Volpe et al., 2016). Cells containing arbuscules need LjTP4 to signal an adequate formation of the arbuscule in the fungus and to improve the absorption of phosphate by the plant (Volpe et al., 2016). When this transporter is expressed at low levels, the structures of the fungus show an abnormal phenotype, with small arbuscules and a swollen and scarcely branched main trunk (Javot et al., 2007; Krajinski et al., 2014; Wang et al., 2014). By silencing the gene LjPT4 through RNA interference, $70 \%$ of the arbuscules presented abnormal phenotype in the PT4i strain, whereas a normal morphology of the arbuscules was observed in GUSi (control) (Volpe et al., 2016). According to these authors, as to the concentration of phosphate in the root, the PT4i strain had lower P content than the GUSi one.

The LjPT4 and MtPT4 transporters are capable of perceiving external levels of $\mathrm{H}_{2} \mathrm{PO}_{4}^{-}$and also of regulating the formation of lateral roots and the interaction with AMF (Volpe et al., 2016). LjPT4 may have a similar mode of action to that of AtNRT1.1 (Remans et al., 2006), a transceptor. Therefore, when detecting the concentration of $\mathrm{H}_{2} \mathrm{PO}_{4}{ }^{-}$in the soil, LjPT4 could activate the transcription factors involved in the formation of lateral roots (Volpe et al., 2016) and that still need to be characterized. The greater branching of the root system under low $\mathrm{H}_{2} \mathrm{PO}_{4}^{-}$concentrations would eventually increase the chances of identifying AMF (Volpe et al., 2016).

From localization experiments, with the fusion between the gene promoter and the codifying region of the GUS reporter protein and with real-time polymerase chain reaction, it was possible to conclude that LjPT4 and MtPT4 are also expressed in the apex of the roots, besides in the periarbuscular membrane; the transcript levels of these carriers were also dependent on phosphate levels (Volpe et al., 2016).
Moreover, mtpt4 mutants showed an increase in the expression of an auxin key receptor, METIR1, at low $\mathrm{P}$ concentrations, increasing the sensitivity of this plant hormone, as well as the formation and emergence of lateral roots (Pérez-Torres et al., 2008).

\section{Joint effect of $N$ and $P$ nutrition on arbuscular mycorrhiza}

The colonization of the host plant is controlled by $\mathrm{N}$ and $\mathrm{P}$ feedback mechanisms; therefore, these two nutrients are crucial for arbuscular mycorrhiza symbiosis (Kiers et al., 2011; Fellbaum et al., 2012, 2014). A deficiency of $P$ and $N$ in plants, for example, induces the stress transcriptome for these nutrients, which is favorable for colonization by AMF (Bücking \& Kafle, 2015). Under this type of stress, the plant decreases the expression levels of defense genes and increases those of the genes involved in the biosynthesis of strigolactone (Bonneau et al., 2013), which acts as an important signal for AMF in the soil, stimulating the branching of their hyphae during the pre-symbiotic phase (Besserer et al., 2006). In most cases, the high availability of $\mathrm{P}$ reduces the colonization of the plant by AMF, but this inhibitory effect is reversed by $\mathrm{N}$ deficiency, which triggers the signals that promote this colonization (Nouri et al., 2014; Breuillin-Sessoms et al., 2015). In addition, under $\mathrm{N}$ deficiency or low $\mathrm{N}$ conditions, respectively, the degeneration of AMF arbuscules is suppressed in mtpt4 mutants and the expression of $\mathrm{P}$ transporters induced by arbuscular mycorrhiza is not critical to this mycorrhiza (Javot et al., 2011).

\section{Plant growth-promoting fungi: recovery efficiency of $\mathbf{N}$ fertilizer}

\section{Arbuscular mycorrhizal fungi}

The negative, neutral, or positive effects of arbuscular mycorrhiza on $\mathrm{N}$ nutrition have been reported (George et al., 1995; Hawkins \& George, 1999; Mensah et al., 2015). When the extraradical mycelium of the AMF G. mosseae was supplemented with 0.2 and 2.0 mmol L L-15 ${ }^{15}$-labeled $\mathrm{NH}_{4} \mathrm{NO}_{3}$, the transport of 1 to $7 \%$ of this compound to 'Hano' wheat (Triticum aestivum L.) was observed (Hawkins \& George, 1999). However, these authors concluded that $\mathrm{N}$ supply by the hyphae was not sufficient to ensure an adequate nutrition of the host pant under limiting $\mathrm{N}$ conditions. Furthermore, studies have shown that 
AMF can increase the intake of $\mathrm{N}$ in colonized plants, in comparison with the uncolonized control (AzcónAguilar et al., 1993; Jin et al., 2005; Bücking \& Kafle, 2015). It should be pointed out that the ability of AMF to enhance the N nutrition of the host plant was relatively dispersed within the Glomeromycota phylum and that, due to high intraspecific diversity, the high symbiotic performance of each isolate is independent of the fungus species to which it belongs to (Mensah et al., 2015). Also according to these authors, among 31 fungal isolates tested, only 6 were able to increase alfalfa (Medicago sativa L.) biomass by more than $170 \%$, compared with the mean, and promoted a 2.4fold increase in $\mathrm{N}$ content in relation to the control.

Studies with transformed carrot roots supplemented with $\mathrm{NO}_{3}{ }^{-}$or $\mathrm{NH}_{4}{ }^{+}$labeled with ${ }^{15} \mathrm{~N}$ showed that the extraradical mycelium of the AMF $G$. intraradices has the ability to transfer from 30 (Govindarajulu et al., 2005 ) to $50 \% \mathrm{~N}$ (Jin et al., 2005) to the transformed roots, and that a large proportion of the root biomass was formed after labeling. In corn, $75 \% \mathrm{~N}$ in the leaves was absorbed by the extraradical mycelium of AMF (Tanaka \& Yano, 2005). Moreover, the ${ }^{15} \mathrm{~N}$ of free amino acids was very high in roots colonized after the addition of $\mathrm{NO}_{3}{ }^{-}$and $\mathrm{NH}_{4}{ }^{+}$labeled with ${ }^{15} \mathrm{~N}$ to the fungal compartment, even when the levels of $\mathrm{N}$ supplemented in colonized roots were three times higher, i.e., went from 4 to $12 \mathrm{mmol} \mathrm{L}^{-1} \mathrm{NO}_{3}{ }^{-}$or $\mathrm{NH}_{4}{ }^{+}$. This shows that the uptake of $\mathrm{N}$ by the extraradical mycelium and its translocation to the colonized roots occur regardless of whether the roots of the host plant are under $\mathrm{N}$ limiting conditions or not (Govindarajulu et al., 2005).

Saia et al. (2014) observed an increase in hard wheat (Triticum durum Desf.) biomass during tillering when inoculated with AMF, in comparison with the noninoculated control, regardless of $\mathrm{N}$ fertilization. Arbuscular mycorrhizae have a positive effect on wheat growth: the colonized plants produced more than 7 and 20\% biomass than the uncolonized control, at 7 and 9 weeks after transplanting, respectively (Saia et al., 2014).

\section{Piriformospora indica}

The endophytic fungus $P$. indica was isolated from the Thar Desert in India. It belongs to the Sebacinaceae family (Sebacinales order) and colonizes roots of several plant species, promoting their growth (Varma et al., 1999; Kumari et al., 2003). Similarly to the arbuscular mycorrhizal symbiosis (Bücking \& Kafle, 2015), $P$. indica symbiosis with plant roots is accompanied by a large $\mathrm{N}$ intake (Sherameti et al., 2005). In fact, Cruz et al. (2013) observed that the absorption rate of $\mathrm{NH}_{4}{ }^{+}$labelled with ${ }^{15} \mathrm{~N}$ by the extraradical mycelium was greater in the tomato- $P$. indica interaction than in tomato-G. intraradices, but was similar to that of the amount transferred to tomato roots. Likewise, Sherameti et al. (2005) found that tobacco (Nicotiana tabacum L.) seedlings inoculated with $P$. indica were larger and heavier, with an increment of $41.0 \pm 4.0 \%$ in dry mass, $42.2 \pm 3.1 \%$ in protein content, $21.4 \pm 4.4 \%$ in shoot $\mathrm{N}$ content, and $50.2 \pm 4.2$ and $12.2 \pm 1.2 \%$ in $\mathrm{NADH}$-dependent nitrate reductase activity in roots and shoots, respectively. These effects were attributed to a higher $\mathrm{NO}_{3}^{-}$uptake and expression of the genes Nia2 and SEX1 encoding $\mathrm{NO}_{3}^{-}$reductase and glucanwater dikinase, respectively, involved in the starch degradation process. The expression of these genes was observed in the roots and shoots of seedlings inoculated with $P$. indica.

\section{Trichoderma spp.}

Trichoderma spp. are endophytic fungal symbionts of plants, able to colonize their roots (epidermis and outer cortical cells) without causing pathological effects, acting as biocontrol agents of diseases and as plant growth promoters (Harman et al., 2004; Shoresh et al., 2010; Harman, 2011). These fungi enhance plant growth and development through the exudation of auxins or other metabolites (Contreras-Cornejo et al., 2009, 2014), which increase the hydrolysis of ATP by PM $\mathrm{H}^{+}$-ATPases, resulting in an increased activity of the enzyme or in a larger extracellular acidification (Lopez-Coria et al., 2016). The auxins and $\mathrm{PM} \mathrm{H}^{+}$ATPases stimulate root elongation (Lopez-Coria et al., 2016) and lateral root branching, enlarging the root surface to be colonized by the fungi and enhancing water and nutrient absorption (Contreras-Cornejo et al., 2009); the $\mathrm{PM} \mathrm{H}^{+}$-ATPases also energize nutrient transport systems. Therefore, the inoculated plants show a better performance in several physiological processes and growth indicators, which translates into greater productivity. In fact, in a commercial corn crop in the USA, the plants inoculated with the biocontrol agent Trichoderma harzianum T-22 (Ascomycete), at different doses of $\mathrm{N}\left(20,40,80,150\right.$, and $\left.240 \mathrm{~kg} \mathrm{ha}^{-1}\right)$, responded more quickly to doses less than or equal 
to $150 \mathrm{~kg} \mathrm{ha}^{-1}$, being greener and larger at the bolting phase and showing greater silage and grain yields at maturation, in comparison with the noninoculated control (Harman, 2000). These same authors also reported that plants inoculated with T-22 showed maximum productivity with less than $38 \% \mathrm{~N}$, when compared with the noninoculated control. Likewise, growth indexes (plant height, leaf number, leaf area, and dry mass of shoots and roots), chlorophyll content, nucleic acids, protein, starch, and phytohormones were increased in corn plants inoculated with air-dried mycelium or T-22 metabolic solution (Akladious \& Abbas, 2014). In addition, rice plants inoculated with Trichoderma spp. and grown in soil in a greenhouse showed increments in plant height, number of leaves, number of tillers, root length, fresh mass of roots, and several physiological processes, such as photosynthesis rate, stomatal conductance, transpiration, internal $\mathrm{CO}_{2}$ concentration, and water use efficiency (Doni et al., 2014).

Data obtained in field conditions with several monocotyledons indicate that the amount of applied fertilizers can be reduced by $40-50 \%$ in the presence of Trichoderma, without reducing productivity (Harman, 2011). Al-Ezerjawi \& Kadhim (2014) found increases in plant height, total $\mathrm{N}$ content, chlorophyll $\mathrm{a}$ and $\mathrm{b}$, 1,000 -grain weight, and grain yield in wheat plants grown under field conditions, using rice straw mulch treated with T. harzianum.

\section{Dark septate endophytic fungi}

Dark septate endophytic(DSE)fungiare ascomycetes characterized by dark pigmentation, septate hyphae, microsclerotia that colonize the epidermis and the root cortex inter- and intracellularly (Figure 4), and also by ubiquity in healthy roots of several plants (Jumpponen $\&$ Trappe, 1998). These fungi were first described by Melin (1922) as Mycelium radicus atrovirens, and the term "dark septate endophytes" was eventually introduced by Stoyke \& Currah (1991).

The DSE fungi makeup a paraphyletic group (Yuan et al., 2011), with saprophytic and symbiotic species (Mandyam \& Jumpponen, 2005) that frequently inhabit oligotrophic soils in all climatic regions, such as arid, semiarid (Barrow \& Aaltonen, 2001; Barrow, 2003), polar (Gardes \& Dahlberg, 1996), and tropical (Pereira et al., 2011; Bonfim et al., 2016; Vergara et al., 2018a) environments.
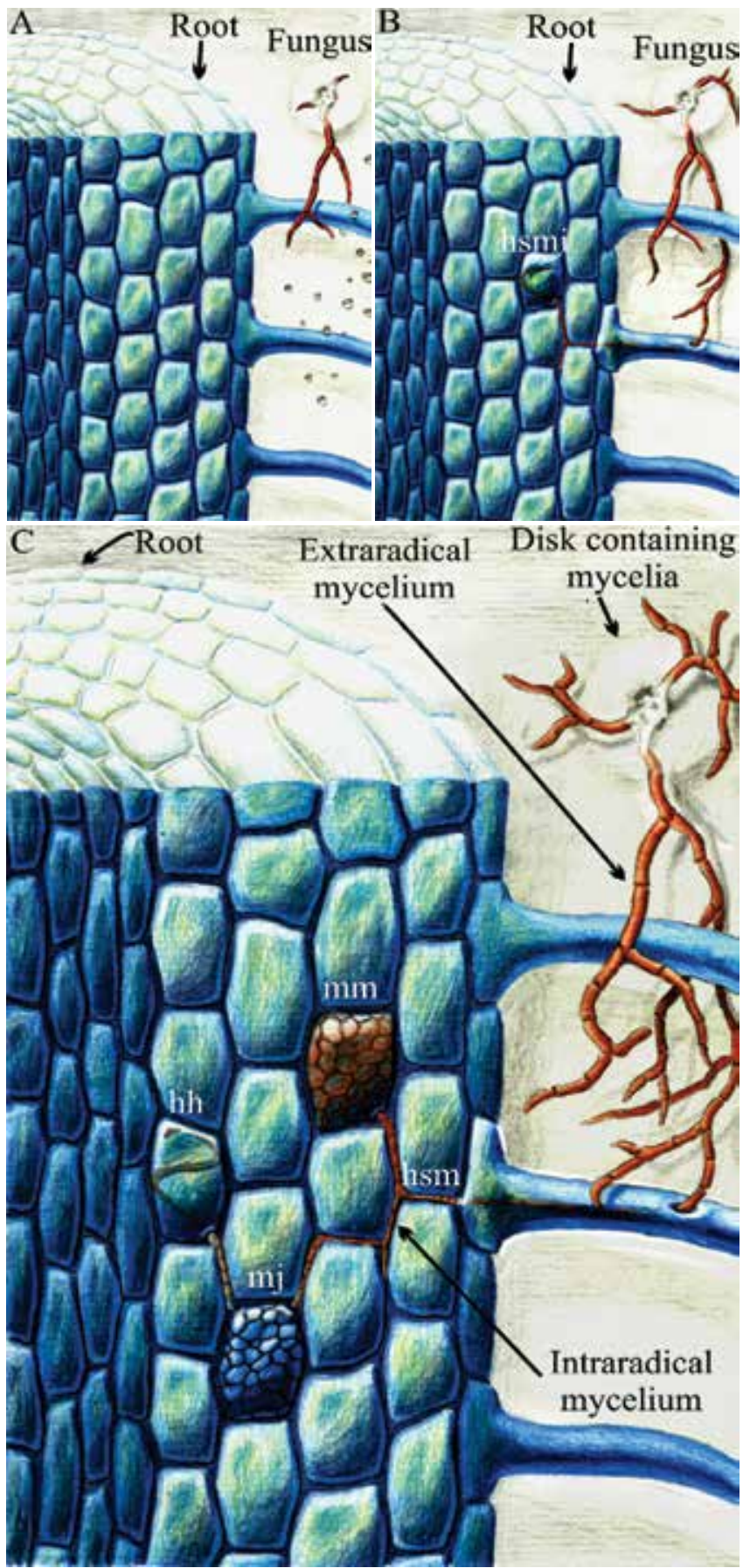

Figure 4. Hypothetical root colonized by a dark septate endophytic (DSE) fungus: A, branching, towards the root system, of the mycelium present in the disk of the culture medium; B, penetration of the hyphae through the root hair, accessing the cells of the cortex; and $\mathrm{C}$, formation of various structures of the DSE fungus in cortex cells, showing the intracellular melanized septate hypha (hsmi), melanized microsclerotia $(\mathrm{mm})$, stained microsclerotia at the young stage (mj), intracellular hyaline septate hypha (hh), and intercellular melanized septate hypha (hsm). 
The mechanism by which DSE fungi establish associations with the host plant is not yet fully understood. However, studies indicate that growth promotion may occur indirectly or directly. The first way would be through plant protection from abiotic stresses, such as drought (Santos et al., 2017; Zhang et al., 2017), salinity (Qin et al., 2017) and high concentrations of heavy metals (Wei et al., 2016), as well as through the production of phytohormones or similar substances (Berthelot et al., 2016). The second would be through the facilitation of nutrient absorption, mainly from organic sources (Usuki \& Narisawa, 2007; Vergara et al., 2018b). In Brassica campestris L., a mutualist association with the DSE fungus Heteroconium chaetospira was observed, in which the fungus supplies $\mathrm{N}$ to the plant and the plant supplies $\mathrm{C}$ to the fungus, causing significant increases in plant biomass (Usuki \& Narisawa, 2007).

The best responses in growth promotion by DSE are observed when organic sources of $\mathrm{N}$ are used (Newsham, 2011; Qin et al., 2017). However, due to the widespread occurrence of DSE fungi in the most diverse environments (Gardes \& Dahlberg, 1996; Sharma \& Jha, 2012), it is likely that these fungi can also assist the plant in the absorption of nutrients from inorganic sources (Usuki \& Narisawa, 2007).

Usuki \& Narisawa (2007) evaluated the ability of $H$. chaetospira to use different amino acids and inorganic $\mathrm{N}$ sources, and observed a significant increase in fungal dry mass in media modified with organic sources of the nutrient, compared with that supplemented with $\mathrm{NH}_{4} \mathrm{NO}_{3}$ or without $\mathrm{N}$. The same authors, while inoculating this fungus in B. campestris supplemented with the same $\mathrm{N}$ sources, found that inoculation promoted the use of all amino acids and $\mathrm{NaNO}_{3}$, with effects on plant growth. Similar results have been reported in the literature (Diene et al., 2013; Mahmoud \& Narisawa, 2013).

In contrast, in cucumber (Cucumis sativus L.) inoculated with the DSE Pseudosigmoidea ibarakiensis and supplemented only with leucine, there was a $44 \%$ reduction in plant dry mass (Diene et al., 2013). However, in rice plants inoculated with DSE fungi, grown under controlled conditions and supplemented with $\mathrm{NH}_{4} \mathrm{NO}_{3}$, significant increments were observed for plant dry matter, $\mathrm{N}$ amino acid, soluble sugars, number of tillers, besides changes in $\mathrm{NO}_{3}{ }^{-}$absorption kinetic parameters $\left(\mathrm{K}_{\mathrm{m}}\right.$ and $\left.\mathrm{V}_{\max }\right)$ (Vergara et al., 2018a).
These authors, based on Zhang et al. (2012), deduced that the reported accumulation of soluble sugars may be related to an increased chlorophyll content and quantum efficiency of the photosystem II in plants inoculated with DSE fungi, indicating that these fungi may also improve the efficiency of the photosynthetic activity of the host plant.

\section{Low-input agriculture}

The green revolution was essential to solve the hunger problems that humanity faced shortly after World War II (Chardon et al., 2012). However, since they were not well evaluated or were simply neglected at the time, the negative impacts of the techniques used to increase agrosystem productivity are only now beginning to emerge, among which stand out fish mortality due to the eutrophication of water bodies (streams, lakes, and rivers), the discovery of nitrosamines (carcinogens) in drinking water (Alaburda \& Nishihara, 1998), and the emission of greenhouse gases (Cerri et al., 2007). These effects have gradually awakened humanity to the use of less inputs in agriculture, which would also decrease the high farmer expenditures due to the excessive use of fertilizers (Chardon et al., 2012). Furthermore, the nonrenewable resources phosphate rocks and phosphate deposits used to manufacture phosphate fertilizers are running out; some analyzes even indicate that, if the current rate of consumption continues, world reserves should only last for approximately 125 years (Gilbert, 2009). Although the production of a quality inoculum, i.e., free of impurities, from AMF is limited because they are obligate biotrophs, these fungi are still an excellent strategy to overcome the cited problems.

The AMF, therefore, show a great potential for the use of oligotrophic soils, without the need to increase nutrients in the soil solution, due to the following reasons: role of the high-affinity transporters of the extraradical mycelium of AMF in absorbing $\mathrm{N}$ (Pérez-Tienda et al., 2012) and $\mathrm{H}_{2} \mathrm{PO}_{4}^{-}$(Thomson et al., 1990; Maldonado-Mendoza et al., 2001); transport of $\mathrm{N}$ to the intraradical mycelium through arginine (Govindarajulu et al., 2005; Tian et al., 2010); and induction of the $\mathrm{H}^{+}$-ATPases of the plant (Ferrol et al., 2002; Krajinski et al., 2014; Wang et al., 2014). Since these fungi are able to contribute with $20-75 \%$ total N of the plant (Govindarajulu et al., 2005; Jin et al., 2005; 
Tanaka \& Yano, 2005), they are a potential approach to reduce the emissions of greenhouse gases and the contamination of water sources. These attributes of AMF can be even more important to ensure an adequate food supply to developing countries, where fertilizer costs are very high, especially for small-scale farmers.

\section{Final considerations}

Although AMF are obligate biotrophs, they present a genome, already sequenced and characterized, with an enzymatic repertoire involved in $\mathrm{N}$ and $\mathrm{P}$ uptake and metabolism, showing the specialization of this group of fungi to extract mineral nutrients from the soil. This has led to increasing researches on other facultative biotrophic fungi, such as $P$. indica, Trichoderma sp., and DSE fungi that are less studied. In AMF, the uptake of nutrients by the extraradical mycelium depends on the plasma membrane $\mathrm{H}^{+}$-ATPase $\mathrm{HA} 5$ and on the transporters of $\mathrm{NH}_{4}{ }^{+}, \mathrm{AMT} 1$, and of $\mathrm{H}_{2} \mathrm{PO}_{4}{ }^{-}, \mathrm{PT}$. While the $\mathrm{N}$ absorbed by the extraradical mycelium of AMF is assimilated and concentrated into arginine via the glutamine synthetase-glutamate synthase pathway, asparagine synthetase, and the anabolic pathway of the urea cycle, $\mathrm{H}_{2} \mathrm{PO}_{4}^{-}$is converted to polyphosphate. Arginine and polyphosphate are transported to the intraradical mycelium, where they are hydrolyzed and converted into $\mathrm{NH}_{4}{ }^{+}$and $\mathrm{H}_{2} \mathrm{PO}_{4}{ }^{-}$. These nutrients are released in the periarbuscular space, inducing the $\mathrm{H}^{+}$-ATPase $\mathrm{HAl}$ and the transporters of $\mathrm{NH}_{4}^{+}$, AMT4.1 and AMT3;1, and of $\mathrm{H}_{2} \mathrm{PO}_{4}^{-}$, PT4, located in the periarbuscular membrane, to initiate the twoway transfer of nutrients, so the host plant receives the mineral nutrients and the fungus receives $\mathrm{C}$. Although further studies are necessary, for instance, to characterize $\mathrm{NO}_{3}{ }^{-}$transporters in the extradical mycelium of AMF and in the host plant, it is clear that this group of fungi can affect plant growth by the absorption of $\mathrm{N}$ and $\mathrm{P}$, changing the agronomic characteristics of a given crop. However, there is a need to investigate which agrosystem management could maximize the beneficial effects of these fungi.

The most favorable kinetic parameters, such as the low $\mathrm{K}_{\mathrm{m}}$ values of the extraradical mycelium of AMF for $\mathrm{N}$ and $\mathrm{P}$ uptake and the induction of $\mathrm{H}^{+}$-ATPases of the plant, indicate a great potential of endophytic fungi for the exploration of oligotrophic soils, without the need to increase the concentration of nutrients in the soil solution. In addition, these parameters can help plant breeders to select genotypes with more sensitive kinetic parameters for detecting nutrients present in the soil, which could improve the recovery efficiency of applied fertilizers, reduce fertilizer expenses, and increase plant dependence on fungal symbionts.

The knowledge generated from studies on arbuscular mycorrhizal symbiosis may help to understand other interactions between plants and other fungi, such as $P$. indica, Trichoderma sp., and DSE fungi, which have been identified as growth promoters. It may also allow of comparisons between these different symbioses, in order to evaluate which of them is more feasible in agronomic terms, and even complement the benefits of each one through the coinoculation of different fungi in a single plant. Cruz et al. (2013), for example, used transformed tomato roots and the isotopic-labeling technique with ${ }^{15} \mathrm{~N}$ to compare the absorbed rates and amount of ${ }^{15} \mathrm{~N}$ transferred from the extraradical mycelium of the AMF $G$. intraradices and $P$. indica to the host plant, and observed that $P$. indica had a higher absorption ${ }^{15} \mathrm{~N}$ rate; however, both fungi transferred the same amount of ${ }^{15} \mathrm{~N}$ to the host plant. Furthermore, the coinoculation of mycorrhizal fungi and DSE fungi already occurs spontaneously in nature, and there are several reports of the coexistence of these fungi in the same root system (Das \& Kayang, 2010); however, the synergy between the host plant and these fungi remains unclear.

\section{References}

AKLADIOUS, S.A.; ABBAS, S.M. Application of Trichoderma harzianum $\mathrm{T} 22$ as a biofertilizer potential in maize growth. Journal of Plant Nutrition, v.37, p.30-49, 2014. DOI: http://dx.doi.org/10.1080/01904167.2013.829100.

AL-EZERJAWI, N.H.; KADHIM, J.H. Effect of two isolates of Trichoderma harzianum on total nitrogen, chlorophyll a \& b contents and yield of wheat (Triticum aestivum L.) class Eba'a-95. International Journal of Science and Research, v.3, p.10781083, 2014. Available at: <https://www.ijsr.net/archive/v3i8/ MDIwMTUzMjg=.pdf>. Accessed on: Aug. 162016.

ALABURDA, J.; NISHIHARA, L. Presença de compostos de nitrogênio em águas de poços. Revista de Saúde Pública, v.32, p.160-165, 1998.

ARANGO, M.; GÉVAUDANT, F.; OUFATTOLE, M.; BOUTRY, $M$. The plasma membrane proton pump ATPase: the significance of gene subfamilies. Planta, v.216, p.355-365, 2003. DOI: http://dx.doi.org/10.1007/s00425-002-0856-8. 
AZCÓN-AGUILAR, C.; ALBA, C.; MONTILLA, M.; BAREA, J.M. Isotopic $\left({ }^{15} \mathrm{~N}\right)$ evidence of the use of less available $\mathrm{N}$ forms by VA mycorrhizas. Symbiosis, v.15, p.39-48, 1993.

BAGO, B.; VIERHEILIG, H.; PICHÉ, Y.; AZCÓN-AGUILAR, C. Nitrate depletion and $\mathrm{pH}$ changes induced by the extraradical mycelium of the arbuscular mycorrhizal fungus Glomus intraradices grown in monoxenic culture. New Phytologist, v.133, p.273-280, 1996. DOI: http://dx.doi.org/10.1111/j.1469-8137.1996. tb01894.x.

BAILlY, J.; DEBAUD, J.-C.; VERNER, M.-C.; PLASSARD, C.; CHALOT, M.; MARMEISSE, R.; FRAISSINET-TACHET, L. How does a symbiotic fungus modulate expression of its hostplant nitrite reductase? New Phytologist, v.175, p.155-165, 2007. DOI: http://dx.doi.org/10.1111/j.1469-8137.2007.02066.x.

BALESTRINI, R.; GÓMEZ-ARIZA, J.; LANFRANCO, L.; BONFANTE, P. Laser microdissection reveals that transcripts for five plant and one fungal phosphate transporter genes are contemporaneously present in arbusculated cells. Molecular Plant-Microbe Interactions, v.20, p.1055-1062, 2007. DOI: http://dx.doi.org/10.1094/MPMI-20-9-1055.

BALESTRINI, R.; LANFRANCO, L. Fungal and plant gene expression in arbuscular mycorrhizal symbiosis. Mycorrhiza, v.16, p.509-524, 2006. DOI: http://dx.doi.org/10.1007/s00572-0060069-2.

BAPAUME, L.; REINHARDT, D. How membranes shape plant symbioses: signaling and transport in nodulation and arbuscular mycorrhiza. Frontiers in Plant Science, v.3, art.223, 2012. DOI: http://dx.doi.org/10.3389/fpls.2012.00223.

BARROW, J.R. Atypical morphology of dark septate fungal root endophytes of Bouteloua in arid southwestern USA rangelands. Mycorrhiza, v.13, p.239-247, 2003. DOI: http://dx.doi.org/10.1007/ S00572-003-0222-0.

BARROW, J.R.; AALTONEN, R.E. Evaluation of the internal colonization of Atriplex canescens (Pursh) Nutt. roots by dark septate fungi and the influence of host physiological activity. Mycorrhiza, v.11, p.199-205, 2001. DOI: http://dx.doi.org/10.1007/ s005720100111.

BENEDETTO, A.; MAGURNO, F.; BONFANTE, P.; LANFRANCO, L. Expression profiles of a phosphate transporter gene $(G m o s P T)$ from the endomycorrhizal fungus Glomus mosseae. Mycorrhiza, v.15, p.620-627, 2005. DOI: http://dx.doi.org/10.1007/s00572-005-0006-9.

BERTHELOT, C.; LEYVAL, C.; FOULON, J.; CHALOT, M.; BLAUDEZ, D. Plant growth promotion, metabolite production and metal tolerance of dark septate endophytes isolated from metalpolluted poplar phytomanagement sites. FEMS Microbiology Ecology, v.92, fiw144, 2016. DOI: http://dx.doi.org/10.1093/ femsec/fiw144.

BESSERER, A.; PUECH-PAGÈS, V.; KIEFER, P.; GOMEZROLDAN, V.; JAUNEAU, A.; ROY, S.; PORTAIS, J.-C.; ROUX, C.; BÉCARD, G.; SÉJALON-DELMAS, N. Strigolactones stimulate arbuscular mycorrhizal fungi by activating mitochondria. PLoS Biology, v.4, e226, 2006. DOI: http://dx.doi.org/10.1371/journal. pbio.0040226.

BONFANTE, P.; GENRE, A. Mechanisms underlying beneficial plant-fungus interactions in mycorrhizal symbiosis. Nature Communications, v.1, art.48, 2010. DOI: http://dx.doi.org/10.1038/ncomms1046.

BONFANTE, P.; REQUENA, N. Dating in the dark: how roots respond to fungal signals to establish arbuscular mycorrhizal symbiosis. Current Opinion in Plant Biology, v.14, p.451-457, 2011. DOI: http://dx.doi.org/10.1016/j.pbi.2011.03.014.

BONFIM, J.A.; VASCONCELLOS, R.L.F.; BALDESIN, L.F.; SIEBER, T.N.; CARDOSO, E.J.B.N. Dark septate endophytic fungi of native plants along an altitudinal gradient in the Brazilian Atlantic forest. Fungal Ecology, v.20, p.202-210, 2016. DOI: http://dx.doi.org/10.1016/j.funeco.2016.01.008.

BONNEAU, L.; HUGUET, S.; WIPF, D.; PAULY, N.; TRUONG, H.-N. Combined phosphate and nitrogen limitation generates a nutrient stress transcriptome favorable for arbuscular mycorrhizal symbiosis in Medicago truncatula. New Phytologist, v.199, p.188202, 2013. DOI: http://dx.doi.org/10.1111/nph.12234.

BREUILLIN-SESSOMS, F.; FLOSS, D.S.; GOMEZ, S.K.; PUMPLIN, N.; DING, Y.; LEVESQUE-TREMBLAY, V.; NOAR, R.D.; DANIELS, D.A.; BRAVO, A.; EAGLESHAM, J.B.; BENEDITO, V.A.; UDVARDI, M.K.; HARRISON, M.J. Suppression of arbuscule degeneration in Medicago truncatula phosphate transporter 4 mutants is dependent on the ammonium transporter 2 family protein AMT2;3. The Plant Cell, v.27, p.1352-1366, 2015. DOI: http://dx.doi.org/10.1105/tpc.114.131144.

BUCHER, M. Functional biology of plant phosphate uptake at root and mycorrhiza interfaces. New Phytologist, v.173, p.11-26, 2007. DOI: http://dx.doi.org/10.1111/j.1469-8137.2006.01935.x.

BÜCKING, H.; HEYSER, W. Uptake and transfer of nutrients in ectomycorrhizal associations: interactions between photosynthesis and phosphate nutrition. Mycorrhiza, v.13, p.5968, 2003. DOI: http://dx.doi.org/10.1007/s00572-002-0196-3.

BÜCKING, H.; KAFLE, A. Role of arbuscular mycorrhizal fungi in the nitrogen uptake of plants: current knowledge and research gaps. Agronomy, v.5, p.587-612, 2015. DOI: http://dx.doi. org/10.3390/agronomy5040587.

BÜCKING, H.; SHACHAR-HILL, Y. Phosphate uptake, transport and transfer by the arbuscular mycorrhizal fungus Glomus intraradices is stimulated by increased carbohydrate availability. New Phytologist, v.165, p.899-912, 2005. DOI: http:// dx.doi.org/10.1111/j.1469-8137.2004.01274.x.

BUN-YA, M.; NISHIMURA, M.; HARASHIMA, S.; OSHIMA, Y. The PHO84 gene of Saccharomyces cerevisiae encodes an inorganic phosphate transporter. Molecular and Cellular Biology, v.11, p.3229-3238, 1991. DOI: http://dx.doi.org/10.1128/ MCB.11.6.3229.

CALABRESE, S.; PÉREZ-TIENDA, J.; ELLERBECK, M.; ARNOULD, C.; CHATAGNIER, O.; BOLLER, T.; SCHÜßLER, A.; BRACHMANN, A.; WIPF, D.; FERROL, N.; COURTY, P.-E. GintAMT3 - a low-affinity ammonium transporter of the arbuscular mycorrhizal Rhizophagus irregularis. Frontiers in Plant Science, v.7, art.679, 2016. DOI: http://dx.doi.org/10.3389/ fpls.2016.00679.

CERRI, C.E.P.; SPAROVEK, G.; BERNOUX, M.; EASTERLING, W.E.; MELILLO, J.M.; CERRI, C.C. Tropical agriculture and 
global warming: impacts and mitigation options. Scientia Agricola, v.64, p.83-99, 2007.

CHARDON, F.; NOËL, V.; MASCLAUX-DAUBRESSE, C. Exploring NUE in crops and in Arabidopsis ideotypes to improve yield and seed quality. Journal of Experimental Botany, v.63, p.3401-3412, 2012. DOI: http://dx.doi.org/10.1093/jxb/err353.

CLIQUET, J.-B.; STEWART, G.R. Ammonia assimilation in Zea mays $\mathrm{L}$. infected with a vesicular-arbuscular mycorrhizal fungus Glomus fasciculatum. Plant Physiology, v.101, p.865-871, 1993. DOI: http://dx.doi.org/10.1104/pp.101.3.865.

CONTRERAS-CORNEJO, H.A.; MACÍAS-RODRÍGUEZ, L.; ALFARO-CUEVAS, R.; LÓPEZ-BUCIO, J. Trichoderma spp. improve growth of Arabidopsis seedlings under salt stress through enhanced root development, osmolite production, and $\mathrm{Na}^{+}$elimination through root exudates. Molecular Plant-Microbe Interactions, v.27, p.503-514, 2014. DOI: http://dx.doi.org/10.1094/MPMI-09-13-0265-R.

CONTRERAS-CORNEJO, H.A.; MACÍAS-RODRÍGUEZ, L.; CORTÉS-PENAGOS, C.; LÓPEZ-BUCIO, J. Trichoderma virens, a plant beneficial fungus, enhances biomass production and promotes lateral root growth through an auxin-dependent mechanism in Arabidopsis. Plant Physiology, v.149, p.1579-1592, 2009. DOI: http://dx.doi.org/10.1104/pp.108.130369.

CRUZ, C.; EGSGAARD, H.; TRUJILLO, C.; AMBUS, P.; REQUENA, N.; MARTINS-LOUÇÃO, M.A.; JAKOBSEN, I. Enzymatic evidence for the key role of arginine in nitrogen translocation by arbuscular mycorrhizal fungi. Plant Physiology, v.144, p.782-792, 2007. DOI: http://dx.doi.org/10.1104/ pp.106.090522.

CRUZ, C.; FEGGHI, Z.; MARTINS-LOUÇÃO, M.A.; VARMA, A. Plant nitrogen use efficiency may be improved through symbiosis with Piriformospora indica. In: VARMA, A.; KOST, G.; OELMÜLLER, R. (Ed.). Piriformospora indica: sebacinales and their biotechnological applications. Heidelberg: Springer, 2013. p.285-293. (Soil Biology, 33). DOI: http://dx.doi.org/10.1007/9783-642-33802-1_17.

D'APUZZO, E.; ROGATO, A.; SIMON-ROSIN, U.; EL ALAOUI, H.; BARBULOVA, A.; BETTI, M.; DIMOU, M.; KATINAKIS, P.; MARQUEZ, A.; MARINI, A.-M.; UDVARDI, M.K.; CHIURAZZI, M. Characterization of three functional high-affinity ammonium transporters in Lotus japonicus with differential transcriptional regulation and spatial expression. Plant Physiology, v.134, p.1763-1774, 2004. DOI: http://dx.doi. org/10.1104/pp.103.034322.

DAS, P.; KAYANG, H. Association of dark septate endophytes and arbuscular mycorrhizal fungi in potato under field conditions in the northeast region of India. Mycology, v.1, p.171-178, 2010. DOI: http://dx.doi.org/10.1080/21501203.2010.517787.

DIENE, O.; WANG, W.; NARISAWA, K. Pseudosigmoidea ibarakiensis sp. nov., a dark septate endophytic fungus from a cedar forest in Ibaraki, Japan. Microbes and Environments, v.28, p.381-387, 2013. DOI: http://dx.doi.org/10.1264/jsme2.ME13002.

DONI, F.; ISAHAK, A.; CHE MOHD ZAIN, C.R.; WAN YUSOFF, W.M. Physiological and growth response of rice plants (Oryza sativa L.) to Trichoderma spp. inoculants. AMB Express, v.4, art.45, 2014. DOI: http://dx.doi.org/10.1186/s13568-014-00458.

DRECHSLER, N.; COURTY, P.-E.; BRULÉ, D.; KUNZE, R. Identification of arbuscular mycorrhiza-inducible Nitrate Transporter 1/Peptide Transporter Family (NPF) genes in rice. Mycorrhiza, v.28, p.93-100, 2018. DOI: http://dx.doi.org/10.1007/ s00572-017-0802-z.

DUBY, G.; BOUTRY, M. The plant plasma membrane proton pump ATPase: a highly regulated P-type ATPase with multiple physiological roles. Pflügers Archiv - European Journal of Physiology, v.457, p.645-655, 2009. DOI: http://dx.doi. org/10.1007/s00424-008-0457-x.

FAURE, S.; CLIQUET, J.-B.; THEPHANY, G.; BOUCAUD, J. Nitrogen assimilation in Lolium perenne colonized by the arbuscular mycorrhizal fungus Glomus fasciculatum. New Phytologist, v.138, p.411-417, 1998. DOI: http://dx.doi. org/10.1046/j.1469-8137.1998.00127.x.

FELLBAUM, C.R.; GACHOMO, E.W.; BEESETTY, Y.; CHOUDHARI, S.; STRAHAN, G.D.; PFEFFER, P.E.; KIERS, E.T.; BÜCKING, H. Carbon availability triggers fungal nitrogen uptake and transport in arbuscular mycorrhizal symbiosis. Proceedings of the National Academy of Sciences, v.109, p.26662671, 2012. DOI: http://dx.doi.org/10.1073/pnas.1118650109.

FELLBAUM, C.R.; MENSAH, J.A.; CLOOS, A.J.; STRAHAN, G.E.; PFEFFER, P.E.; KIERS, E.T.; BÜCKING, H. Fungal nutrient allocation in common mycorrhizal networks is regulated by the carbon source strength of individual host plants. New Phytologist, v.203, p.646-656, 2014. DOI: http://dx.doi.org/10.1111/nph.12827.

FERROL, N.; BAREA, J.M.; AZCÓN-AGUILAR, C. The plasma membrane $\mathrm{H}^{+}$-ATPase gene family in the arbuscular mycorrhizal fungus Glomus mosseae. Current Genetics, v.37, p.112-118, 2000. DOI: http://dx.doi.org/10.1007/s002940050017.

FERROL, N.; POZO, M.J.; ANTELO, M.; AZCÓN-AGUILAR, C. Arbuscular mycorrhizal symbiosis regulates plasma membrane $\mathrm{H}^{+}$-ATPase gene expression in tomato plants. Journal of Experimental Botany, v.53, p.1683-1687, 2002. DOI: http:// dx.doi.org/10.1093/jxb/erf014.

FIORILLI, V.; LANFRANCO, L.; BONFANTE, P. The expression of GintPT, the phosphate transporter of Rhizophagus irregularis, depends on the symbiotic status and phosphate availability. Planta, v.237, p.1267-1277, 2013. DOI: http://dx.doi.org/10.1007/ s00425-013-1842-z.

GACHOMO, E.; ALLEN, J.W.; PFEFFER, P.E.; GOVINDARAJULU, M.; DOUDS, D.D.; JIN, H.; NAGAHASHI, G.; LAMMERS, P.J.; SHACHAR-HILL, Y.; BÜCKING, H. Germinating spores of Glomus intraradices can use internal and exogenous nitrogen sources for de novo biosynthesis of amino acids. New Phytologist, v.184, p.399-411, 2009. DOI: http://dx.doi.org/10.1111/j.1469-8137.2009.02968.x.

GARDES, M.; DAHLBERG, A. Mycorrhizal diversity in arctic and alpine tundra: an open question. New Phytologist, v.133, p.147-157, 1996. DOI: http://dx.doi.org/10.1111/j.1469-8137.1996. tb04350.x. 
GAXIOLA, R.A.; PALMGREN, M.G.; SCHUMACHER, K. Plant proton pumps. FEBS Letters, v.581, p.2204-2214, 2007. DOI: http://dx.doi.org/10.1016/j.febslet.2007.03.050.

GENRE, A.; CHABAUD, M.; BALZERGUE, C.; PUECHPAGÈS, V.; NOVERO, M.; REY, T.; FOURNIER, J.; ROCHANGE, S.; BÉCARD, G.; BONFANTE, P.; BARKER, D.G. Short-chain chitin oligomers from arbuscular mycorrhizal fungi trigger nuclear $\mathrm{Ca}^{2+}$ spiking in Medicago truncatula roots and their production is enhanced by strigolactone. New Phytologist, v.198, p.179-189, 2013. DOI: http://dx.doi.org/10.1111/nph.12146.

GEORGE, E.; MARSCHNER, H.; JAKOBSEN, I. Role of arbuscular mycorrhizal fungi in uptake of phosphorus and nitrogen from soil. Critical Reviews in Biotechnology, v.15, p.257-270, 1995. DOI: http://dx.doi.org/10.3109/07388559509147412.

GIANINAZZI-PEARSON, V.; ARNOULD, C.; OUFATTOLE, M.; ARANGO, M.; GIANINAZZI, S. Differential activation of $\mathrm{H}^{+}$-ATPase genes by an arbuscular mycorrhizal fungus in root cells of transgenic tobacco. Planta, v.211, p.609-613, 2000. DOI: http://dx.doi.org/10.1007/s004250000323.

GIANINAZZI-PEARSON, V.; SMITH, S.E.; GIANINAZZI, S.; SMITH, F.A. Enzymatic studies on the metabolism of vesiculararbuscular mycorrhizas. New Phytologist, v.117, p.61-74, 1991. DOI: http://dx.doi.org/10.1111/j.1469-8137.1991.tb00945.x.

GILBERT, N. Environment: the disappearing nutrient. Nature, v.461, p.716-718, 2009. DOI: http://dx.doi.org/10.1038/461716a.

GOMEZ, S.K.; JAVOT, H.; DEEWATTHANAWONG, P.; TORRES-JEREZ, I.; TANG, Y.; BLANCAFLOR, E.B.; UDVARDI, M.K.; HARRISON, M.J. Medicago truncatula and Glomus intraradices gene expression in cortical cells harboring arbuscules in the arbuscular mycorrhizal symbiosis. BMC Plant Biology, v.9, p.1-19, 2009. DOI: http://dx.doi.org/10.1186/14712229-9-10.

GOVINDARAJULU, M.; PFEFFER, P.E.; JIN, H.; ABUBAKER, J.; DOUDS, D.D.; ALLEN, J.W.; BÜCKING, H.; LAMMERS, P.J.; SHACHAR-HILL, Y. Nitrogen transfer in the arbuscular mycorrhizal symbiosis. Nature, v.435, p.819-823, 2005. DOI: http://dx.doi.org/10.1038/nature03610.

GUESCINI, M.; ZEPPA, S.; PIERLEONI, R.; SISTI, D.; STOCCHI, L.; STOCCHI, V. The expression profile of the Tuber borchii nitrite reductase suggests its positive contribution to host plant nitrogen nutrition. Current Genetics, v.51, p.31-41, 2007. DOI: http://dx.doi.org/10.1007/s00294-006-0105-y.

GUETHER, M.; NEUHÄUSER, B.; BALESTRINI, R.; DYNOWSKI, M.; LUDEWIG, U.; BONFANTE, P. A mycorrhizalspecific ammonium transporter from Lotus japonicus acquires nitrogen released by arbuscular mycorrhizal fungi. Plant Physiology, v.150, p.73-83, 2009. DOI: http://dx.doi.org/10.1104/ pp.109.136390.

HAJONG, S.; KUMARIA, S.; TANDON, P. Comparative study of key phosphorus and nitrogen metabolizing enzymes in mycorrhizal and non-mycorrhizal plants of Dendrobium chrysanthum Wall. ex Lindl. Acta Physiologiae Plantarum, v.35, p.2311-2322, 2013. DOI: http://dx.doi.org/10.1007/s11738013-1268-z.
HAMMER, E.C.; PALLON, J.; WALLANDER, H.; OLSSON, P.A. Tit for tat? A mycorrhizal fungus accumulates phosphorus under low plant carbon availability. FEMS Microbiology Ecology, v.76, p.236-244, 2011. DOI: http://dx.doi.org/10.1111/ j.1574-6941.2011.01043.x.

HARMAN, G.E. Multifunctional fungal plant symbionts: new tools to enhance plant growth and productivity. New Phytologist, v.189, p.647-649, 2011. DOI: http://dx.doi.org/10.1111/j.14698137.2010.03614.x.

HARMAN, G.E. Myths and dogmas of biocontrol changes in perceptions derived from research on Trichoderma harzianum T-22. Plant Disease, v.84, p.377-393, 2000. DOI: http://dx.doi.org/10.1094/PDIS.2000.84.4.377.

HARMAN, G.E.; HOWELL, C.R.; VITERBO, A.; CHET, I.; LORITO, M. Trichoderma species - opportunistic, avirulent plant symbionts. Nature Reviews Microbiology, v.2, p.43-56, 2004. DOI: http://dx.doi.org/10.1038/nrmicro797.

HARRISON, M.J. Cellular programs for arbuscular mycorrhizal symbiosis. Current Opinion in Plant Biology, v.15, p.691-698, 2012. DOI: http://dx.doi.org/10.1016/j.pbi.2012.08.010.

HARRISON, M.J. Signaling in the arbuscular mycorrhizal symbiosis. Annual Review of Microbiology, v.59, p.19-42, 2005. DOI: http://dx.doi.org/10.1146/annurev.micro.58.030603.123749.

HARRISON, M.J.; DEWBRE, G.R.; LIU, J. A phosphate transporter from Medicago truncatula involved in the acquisition of phosphate released by arbuscular mycorrhizal fungi. The Plant Cell, v.14, p.2413-2429, 2002. DOI: http://dx.doi.org/10.1105/ tpc.004861.

HARRISON, M.J.; VAN BUUREN, M.L. A phosphate transporter from the mycorrhizal fungus Glomus versiforme. Nature, v.378, p.626-629, 1995. DOI: http://dx.doi.org/10.1038/378626a0.

HAWKINS, H.-J.; GEORGE, E. Effect of plant nitrogen status on the contribution of arbuscular mycorrhizal hyphae to plant nitrogen uptake. Physiologia Plantarum, v.105, p.694-700, 1999. DOI: http://dx.doi.org/10.1034/j.1399-3054.1999.105414.x.

HILDEBRANDT, U.; SCHMELZER, E.; BOTHE, H. Expression of nitrate transporter genes in tomato colonized by an arbuscular mycorrhizal fungus. Physiologia Plantarum, v.115, p.125-136, 2002. DOI: http://dx.doi.org/10.1034/j.1399-3054.2002.1150115.x.

HOLFORD, I.C.R. Soil phosphorus: its measurement, and its uptake by plants. Australian Journal of Soil Research, v.35, p.227-240, 1997. DOI: http://dx.doi.org/10.1071/S96047.

HOWITT, S.M.; UDVARDI, M.K. Structure, function and regulation of ammonium transporters in plants. Biochimica et Biophysica Acta. Biomembranes, v.1465, p.152-170, 2000. DOI: http://dx.doi.org/10.1016/S0005-2736(00)00136-X.

JAKOBSEN, I.; ABBOTT, L.K.; ROBSON, A.D. External hyphae of vesicular-arbuscular mycorrhizal fungi associated with Trifolium subterraneum L. New Phytologist, v.120, p.371-380, 1992. DOI: http://dx.doi.org/10.1111/j.1469-8137.1992.tb01077.x.

JANICKA-RUSSAK, M. Plant plasma membrane $\mathrm{H}^{+}$-ATPase in adaptation of plants to abiotic stresses. In: SHANKER, A.K.; VENKATESWARLU, B. (Ed.). Abiotic stress response in plants- 
physiological, biochemical and genetic perspectives. Rijeka: InTech, 2011. p.197-218. DOI: http://dx.doi.org/10.5772/24121.

JAVELLE, A.; CHALOT, M.; SÖDERSTRÖM, B.; BOTTON, B. Ammonium and methylamine transport by the ectomycorrhizal fungus Paxillus involutus and ectomycorrhizas. FEMS Microbiology Ecology, v.30, p.355-366, 1999. DOI: http://dx.doi.org/10.1111/j.1574-6941.1999.tb00663.x.

JAVELLE， A.; MOREL, M.; RODRÍGUEZ-PASTRANA, B.-R.; BOTTON, B.; ANDRÉ, B.; MARINI, A.-M.; BRUN, A.; CHALOT, M. Molecular characterization, function and regulation of ammonium transporters (Amt) and ammoniummetabolizing enzymes (GS, NADP-GDH) in the ectomycorrhizal fungus Hebeloma cylindrosporum. Molecular Microbiology, v.47, p.411-430, 2003. DOI: http://dx.doi.org/10.1046/j.13652958.2003.03303.x.

JAVELLE, A.; RODRÍGUEZ-PASTRANA, B.-R.; JACOB, C.; BOTTON, B.; BRUN, A.; ANDRÉ, B.; MARINI, A.-M.; CHALOT, M. Molecular characterization of two ammonium transporters from the ectomycorrhizal fungus Hebeloma cylindrosporum. FEBS Letters, v.505, p.393-398, 2001. DOI: http://dx.doi.org/10.1016/S0014-5793(01)02802-2.

JAVOT, H.; PENMETSA, R.V.; BREUILLIN, F.; BHATTARAI, K.K.; NOAR, R.D.; GOMEZ, S.K.; ZHANG, Q.; COOK, D.R.; HARRISON, M.J. Medicago truncatula mtpt4 mutants reveal a role for nitrogen in the regulation of arbuscule degeneration in arbuscular mycorrhizal symbiosis. The Plant Journal, v.68, p.954-965, 2011. DOI: http://dx.doi.org/10.1111/j.1365313X.2011.04746.x.

JAVOT, H.; PENMETSA, R.V.; TERZAGHI, N.; COOK, D.R.; HARRISON, M.J. A Medicago truncatula phosphate transporter indispensable for the arbuscular mycorrhizal symbiosis. Proceedings of the National Academy of Sciences, v.104, p.17201725, 2007. DOI: http://dx.doi.org/10.1073/pnas.0608136104.

JENNINGS, D.H. The physiology of fungal nutrition. Cambridge: Cambridge University Press, 1995. DOI: http://dx.doi.org/10.1017/CBO9780511525421.

JIN, H.; PFEFFER, P.E.; DOUDS, D.D.; PIOTROWSKI, E.; LAMMERS, P.J.; SHACHAR-HILL, Y. The uptake, metabolism, transport and transfer of nitrogen in an arbuscular mycorrhizal symbiosis. New Phytologist, v.168, p.687-696, 2005. DOI: http://dx.doi.org/10.1111/j.1469-8137.2005.01536.x.

JONGBLOED, R.H.; CLEMENT, J.M.A.M.; BORST-PAUWELS, G.W.F.H. Kinetics of $\mathrm{NH}_{4}^{+}$and $\mathrm{K}^{+}$uptake by ectomycorrhizal fungi. Effect of $\mathrm{NH}_{4}^{+}$on $\mathrm{K}^{+}$uptake. Physiologia Plantarum, v.83, p.427-432, 1991. DOI: http://dx.doi.org/10.1111/j.1399-3054.1991. tb00116.x.

JUMPPONEN, A.; TRAPPE, J.M. Dark septate endophytes: a review of facultative biotrophic root-colonizing fungi. New Phytologist, v.140, p.295-310, 1998. DOI: http://dx.doi. org/10.1046/j.1469-8137.1998.00265.x.

KALDORF, M.; SCHMELZER, E.; BOTHE, H. Expression of maize and fungal nitrate reductase genes in arbuscular mycorrhiza. Molecular Plant-Microbe Interactions, v.11, p.439448, 1998. DOI: http://dx.doi.org/10.1094/MPMI.1998.11.6.439.
KARANDASHOV, V.; BUCHER, M. Symbiotic phosphate transport in arbuscular mycorrhizas. Trends in Plant Science, v.10, p.22-29, 2005. DOI: http://dx.doi.org/10.1016/j. tplants.2004.12.003.

KERCHOVE D'EXAERDE, A. de; SUPPLY, P.; GOFFEAU, A. Subcellular traffic of the plasma membrane $\mathrm{H}^{+}$-ATPase in Saccharomycescerevisiae. Yeast,v.12,p.907-916,1996.DOI:http:// dx.doi.org/10.1002/(SICI)1097-0061(199608)12:10<907::AIDYEA10>3.0.CO;2-2.

KERSTEN, M.A.S.H.; ARNINKHOF, M.J.C.; OP DEN CAMP, H.J.M.; VAN GRIENSVEN, L.J.L.D.; VAN DER DRIFT, C. Transport of amino acids and ammonium in mycelium of Agaricus bisporus. Biochimica et Biophysica Acta. General Subjects, v.1428, p.260-272, 1999. DOI: http://dx.doi.org/10.1016/ S0304-4165(99)00093-8.

KIERS, E.T.; DUHAMEL, M.; BEESETTY, Y.; MENSAH, J.A.; FRANKEN, O.; VERBRUGGEN, E.; FELLBAUM, C.R.; KOWALCHUK, G.A.; HART, M.M.; BAGO, A.; PALMER, T.M.; WEST, S.A.; VANDENKOORNHUYSE, P.; JANSA, J.; BÜCKING, H. Reciprocal rewards stabilize cooperation in the mycorrhizal symbiosis. Science, v.333, p.880-882, 2011. DOI: http://dx.doi.org/10.1126/science.1208473.

KOBAE, Y.; TAMURA, Y.; TAKAI, S.; BANBA, M.; HATA, S. Localized expression of arbuscular mycorrhiza-inducible ammonium transporters in soybean. Plant \& Cell Physiology, v.51, p.1411-1415, 2010. DOI: http://dx.doi.org/10.1093/pcp/pcq099.

KOEGEL, S.; AIT LAHMIDI, N.; ARNOULD, C.; CHATAGNIER, O.; WALDER, F.; INEICHEN, K.; BOLLER, T.; WIPF, D.; WIEMKEN, A.; COURTY, P.E. The family of ammonium transporters (AMT) in Sorghum bicolor: two AMT members are induced locally, but not systemically in roots colonized by arbuscular mycorrhizal fungi. New Phytologist, v.198, p.853-865, 2013. DOI: http://dx.doi.org/10.1111/nph.12199.

KOEGEL, S.; BRULÉ, D.; WIEMKEN, A.; BOLLER, T.; COURTY, P.-E. The effect of different nitrogen sources on the symbiotic interaction between Sorghum bicolor and Glomus intraradices: expression of plant and fungal genes involved in nitrogen assimilation. Soil Biology \& Biochemistry, v.86, p.159163, 2015. DOI: http://dx.doi.org/10.1016/j.soilbio.2015.03.003.

KRAJINSKI, F.; COURTY, P.-E.; SIEH, D.; FRANKEN, P.; ZHANG, H.; BUCHER, M.; GERLACH, N.; KRYVORUCHKO, I.; ZOELLER, D.; UDVARDI, M.; HAUSE, B. The $\mathrm{H}^{+}$-ATPase HA1 of Medicago truncatula is essential for phosphate transport and plant growth during arbuscular mycorrhizal symbiosis. The Plant Cell, v.26, p.1808-1817, 2014. DOI: http://dx.doi.org/10.1105/ tpc.113.120436.

KUMARI, R.; KISHAN, H.; BHOON, Y.K.; VARMA, A. Colonization of cruciferous plants by Piriformospora indica. Current Science, v.85, p.1672-1674, 2003.

LAMOUREUX, G.; JAVELLE, A.; BADAY, S.; WANG, S.; BERNĖCHE, S. Transport mechanisms in the ammonium transporter family. Transfusion Clinique et Biologique, v.17, p.168-175, 2010. DOI: http://dx.doi.org/10.1016/j. tracli.2010.06.004. 
LIU, J.; LIU, J.; CHEN, A.; JI, M.; CHEN, J.; YANG, X.; GU, M.; QU, H.; XU, G. Analysis of tomato plasma membrane $\mathrm{H}^{+}-$ ATPase gene family suggests a mycorrhiza-mediated regulatory mechanism conserved in diverse plant species. Mycorrhiza, v.26, p.645-656, 2016. DOI: http://dx.doi.org/10.1007/s00572-0160700-9.

LÓPEZ-CORIA, M.; HERNÁNDEZ-MENDOZA， J.L.; SÁNCHEZ-NIETO, S. Trichoderma asperellum induces maize seedling growth by activating the plasma membrane $\mathrm{H}^{+}$-ATPase. Molecular Plant-Microbe Interactions, v.29, p.797-806, 2016. DOI: http://dx.doi.org/10.1094/mpmi-07-16-0138-r.

LÓPEZ-PEDROSA, A.; GONZÁLEZ-GUERRERO, M.; VALDERAS, A.; AZCÓN-AGUILAR, C.; FERROL, N. GintAMT1 encodes a functional high-affinity ammonium transporter that is expressed in the extraradical mycelium of Glomus intraradices. Fungal Genetics and Biology, v.43, p.102110, 2006. DOI: http://dx.doi.org/10.1016/j.fgb.2005.10.005.

MAHMOUD, R.S.; NARISAWA, K. A new fungal endophyte, Scolecobasidium humicola, promotes tomato growth under organic nitrogen conditions. PloS One, v.8, e78746, 2013. DOI: http://dx.doi.org/10.1371/journal.pone.0078746.

MAILLET, F.; POINSOT, V.; ANDRÉ, O.; PUECH-PAGÈS, V.; HAOUY, A.; GUEUNIER, M.; CROMER, L.; GIRAUDET, D.; FORMEY, D.; NIEBEL, A.; MARTINEZ, E.A.; DRIGUEZ, H.; BÉCARD, G.; DÉNARIÉ, J. Fungal lipochitooligosaccharide symbiotic signals in arbuscular mycorrhiza. Nature, v.469, p.5864, 2011. DOI: http://dx.doi.org/10.1038/nature09622.

MALDONADO-MENDOZA, I.E.; DEWBRE, G.R.; HARRISON, M.J. A phosphate transporter gene from the extra-radical mycelium of an arbuscular mycorrhizal fungus Glomus intraradices is regulated in response to phosphate in the environment. Molecular Plant-Microbe Interactions, v.14, p.1140-1148, 2001. DOI: http://dx.doi.org/10.1094/ MPMI.2001.14.10.1140.

MANDYAM, K.; JUMPPONEN, A. Seeking the elusive function of the root-colonising dark septate endophytic fungi. Studies in Mycology, v.53, p.173-189, 2005. DOI: http://dx.doi.org/10.3114/ $\operatorname{sim} .53 .1 .173$.

MARINI, A.M.; SOUSSI-BOUDEKOU, S.; VISSERS, S.; ANDRE, B. A family of ammonium transporters in Saccharomyces cerevisiae. Molecular and Cellular Biology, v.17, p.4282-4293, 1997. DOI: http://dx.doi.org/10.1128/mcb.17.8.4282.

MARINI, A.-M.; VISSERS, S.; URRESTARAZU, A.; ANDRÉ, B. Cloning and expression of the MEP1 gene encoding an ammonium transporter in Saccharomyces cerevisiae. The Embo Journal, v.13, p.3456-3463, 1994.

MARZLUF, G.A. Regulation of nitrogen metabolism in mycelial fungi. In: BRAMBL, R.; MARZLUF, G.A. (Ed.). Biochemistry and molecular biology. Heidelberg: Springer, 1996. p.357-368. (The mMycota: a comprehensive treatise on fungi as experimental systems for basic and applied research, 3).

MELIN, E. On the mycorrhizas of Pinus sylvestris L. and Picea abies Karst. A preliminary note. Journal of Ecology, v.9, p.254257, 1922. DOI: http://dx.doi.org/10.2307/2255406.
MENSAH, J.A.; KOCH, A.M.; ANTUNES, P.M.; KIERS, E.T.; HART, M.; BÜCKING, H. High functional diversity within species of arbuscular mycorrhizal fungi is associated with differences in phosphate and nitrogen uptake and fungal phosphate metabolism. Mycorrhiza, v.25, p.533-546, 2015. DOI: http://dx.doi.org/10.1007/s00572-015-0631-x.

MONTANINI, B.; MORETTO, N.; SORAGNI, E.; PERCUDANI, R.; OTTONELLO, S. A high-affinity ammonium transporter from the mycorrhizal ascomycete Tuber borchii. Fungal Genetics and Biology, v.36, p.22-34, 2002. DOI: http://dx.doi.org/10.1016/ S1087-1845(02)00001-4.

MURPHY, P.J.; LANGRIDGE, P.; SMITH, S.E. Cloning plant genes differentially expressed during colonization of roots of Hordeum vulgare by the vesicular-arbuscular mycorrhizal fungus Glomus intraradices. New Phytologist, v.135, p.291-301, 1997. DOI: http://dx.doi.org/10.1046/j.1469-8137.1997.00652.x.

NAVARRO, F.J.; MACHÍN, F.; MARTÍN, Y.; SIVERIO, J.M. Down-regulation of eukaryotic nitrate transporter by nitrogendependent ubiquitinylation. Journal of Biological Chemistry, v.281, p.13268-13274, 2006. DOI: http://dx.doi.org/10.1074/jbc. M601253200.

NEWSHAM, K.K. A meta-analysis of plant responses to dark septate root endophytes. New Phytologist, v.190, p.783-793, 2011. DOI: http://dx.doi.org/10.1111/j.1469-8137.2010.03611.x.

NOURI, E.; BREUILLIN-SESSOMS, F.; FELLER, U.; REINHARDT, D. Phosphorus and nitrogen regulate arbuscular mycorrhizal symbiosis in Petunia hybrida. PLoS One, v.9, e90841, 2014. DOI: http://dx.doi.org/10.1371/journal.pone.0090841.

OLDROYD, G.E.D. Speak, friend, and enter: signalling systems that promote beneficial symbiotic associations in plants. Nature Reviews Microbiology, v.11, p.252-263, 2013. DOI: http://dx.doi.org/10.1038/nrmicro2990.

OLSSON, P.A.; RAHM, J.; ALIASGHARZAD, N. Carbon dynamics in mycorrhizal symbioses is linked to carbon costs and phosphorus benefits. FEMS Microbiology Ecology, v.72, p.125-131, 2010. DOI: http://dx.doi.org/10.1111/j.15746941.2009.00833.x.

PARNISKE, M. Arbuscular mycorrhiza: the mother of plant root endosymbioses. Nature Reviews Microbiology, v.6, p.763-775, 2008. DOI: http://dx.doi.org/10.1038/nrmicro1987.

PASZKOWSKI, U.; KROKEN, S.; ROUX, C.; BRIGGS, S.P. Rice phosphate transporters include an evolutionarily divergent gene specifically activated in arbuscular mycorrhizal symbiosis. Proceedings of the National Academy of Sciences, v.99, p.1332413329, 2002. DOI: http://dx.doi.org/10.1073/pnas.202474599.

PEREIRA, G.M.D.; RIBEIRO, K.G.; FERNANDES JÚNIOR, P.I.; VITAL, M.J.S.; KASUYA, M.C.M.; ZILLI, J.É. Ocorrência de fungos endofíticos "dark septate" em raízes de Oryza glumaepatula na Amazônia. Pesquisa Agropecuária Brasileira, v.46, p.331-334, 2011. DOI: http://dx.doi.org/10.1590/S0100204X2011000300015.

PÉREZ-TIENDA, J.; CORRÊA, A.; AZCÓN-AGUILAR, C.; FERROL, N. Transcriptional regulation of host $\mathrm{NH}_{4}{ }^{+}$transporters and GS/GOGAT pathway in arbuscular mycorrhizal rice roots. 
Plant Physiology and Biochemistry, v.75, p.1-8, 2014. DOI: http://dx.doi.org/10.1016/j.plaphy.2013.11.029.

PÉREZ-TIENDA， J.; TESTILLANO, P.S.; BALESTRINI, R.; FIORILLI, V.; AZCÓN-AGUILAR, C.; FERROL, N. GintAMT2, a new member of the ammonium transporter family in the arbuscular mycorrhizal fungus Glomus intraradices. Fungal Genetics and Biology, v.48, p.1044-1055, 2011. DOI: http://dx.doi.org/10.1016/j.fgb.2011.08.003.

PÉREZ-TIENDA， J.; VALDERAS， A.; CAMAÑES， G.; GARCÍA-AGUSTÍN, P.; FERROL, N. Kinetics of $\mathrm{NH}_{4}^{+}$ uptake by the arbuscular mycorrhizal fungus Rhizophagus irregularis. Mycorrhiza, v.22, p.485-491, 2012. DOI: http://dx.doi.org/10.1007/s00572-012-0452-0.

PÉREZ-TORRES, C.-A.; LÓPEZ-BUCIO, J.; CRUZ-RAMÍREZ, A.; IBARRA-LACLETTE, E.; DHARMASIRI, S.; ESTELLE, M.; HERRERA-ESTRELLA, L. Phosphate availability alters lateral root development in Arabidopsis by modulating auxin sensitivity via a mechanism involving the TIR1 auxin receptor. The Plant Cell, v.20, p.3258-3272, 2008. DOI: http://dx.doi.org/10.1105/tpc.108.058719.

PUMPLIN, N.; HARRISON, M.J. Live-Cell imaging reveals periarbuscular membrane domains and organelle location in Medicago truncatula roots during arbuscular mycorrhizal symbiosis. Plant Physiology, v.151, p.809-819, 2009. DOI: http://dx.doi.org/10.1104/pp.109.141879.

QIN, Y.; PAN, X.; KUBICEK, C.; DRUZHININA, I.; CHENTHAMARA, K.; LABBÉ, J.; YUAN, Z. Diverse plantassociated pleosporalean fungi from saline areas: ecological tolerance and nitrogen-status dependent effects on plant growth. Frontier Microbiology, v.8, art.158, 2017. DOI: http://dx.doi.org/10.3389/fmicb.2017.00158.

RANI, B.; MADAN, S.; SHARMA, K.D.; POOJA, , M.K.B; KUMAR, A. Effect of mycorrhizal colonization on nitrogen and phosphorous metabolism in wheat (Triticum aestivum L.) under water deficit stress. International Journal of Current Microbiology and Applied Sciences, v.6, p.916-929, 2017. DOI: http://dx.doi.org/10.20546/ijcmas.2017.610.110.

REDECKER, D.; KODNER, R.; GRAHAM, L.E. Glomalean fungi from the Ordovician. Science, v.289, p.1920-1921, 2000. DOI: http://dx.doi.org/10.1126/science.289.5486.1920.

REMANS, T.; NACRY, P.; PERVENT, M.; FILLEUR, S.; DIATLOFF, E.; MOUNIER, E.; TILLARD, P.; FORDE, B.G.; GOJON, A. The Arabidopsis NRT1.1 transporter participates in the signaling pathway triggering root colonization of nitrate-rich patches. Proceedings of the National Academy of Sciences, v.103, p.19206-19211, 2006. DOI: http://dx.doi.org/10.1073/ pnas.0605275103.

REQUENA, N.; BREUNINGER, M.; FRANKEN, P.; OCÓN, A. Symbiotic status, phosphate, and sucrose regulate the expression of two plasma membrane $\mathrm{H}^{+}$-ATPase genes from the mycorrhizal fungus Glomus mosseae. Plant Physiology, v.132, p.1540-1549, 2003. DOI: http://dx.doi.org/10.1104/pp.102.019042.

RYAN, M.H.; MCCULLY, M.E.; HUANG, C.X. Relative amounts of soluble and insoluble forms of phosphorus and other elements in intraradical hyphae and arbuscules of arbuscular mycorrhizas.
Functional Plant Biology, v.34, p.457-464, 2007. DOI: http://dx.doi.org/10.1071/FP06242.

SAIA, S.; BENÍTEZ, E.; GARCÍA-GARRIDO, J.M.; SETTANNI, L.; AMATO, G.; GIAMBALVO, D. The effect of arbuscular mycorrhizal fungi on total plant nitrogen uptake and nitrogen recovery from soil organic material. Journal of Agricultural Science, v.152, p.370-378, 2014. DOI: http://dx.doi.org/10.1017/ S002185961300004X.

SANTOS, S.G. dos; SILVA, P.R.A. da; GARCIA, A.C.; ZILLI, J.E.; BERBARA, R.L.L. Dark septate endophyte decreases stress on rice plants. Brazilian Journal of Microbiology, v.48, p.333341, 2017. DOI: http://dx.doi.org/10.1016/j.bjm.2016.09.018.

SHARMA, B.B.; JHA, D.K. Arbuscular mycorrhiza and dark septate fungal associations in medicinal and aromatic plants of Guwahati. Journal of Microbiology and Biotechnology Research, v.2, p.212-222, 2012. Available at: <https://jmbronline. com/index.php/JMBR/article/view/101>. Acessed on: Jun. 62016.

SHERAMETI, I.; SHAHOLLARI, B.; VENUS, Y.; ALTSCHMIED, L.; VARMA, A.; OELMÜLLER, R. The endophytic fungus Piriformospora indica stimulates the expression of nitrate reductase and the starch-degrading enzyme glucan-water dikinase in tobacco and Arabidopsis roots through a homeodomain transcription factor that binds to a conserved motif in their promoters. Journal of Biological Chemistry, v.280, p.26241-26247, 2005. DOI: http://dx.doi.org/10.1074/jbc. M500447200.

SHORESH, M.; HARMAN, G.E.; MASTOURI, F. Induced systemic resistance and plant responses to fungal biocontrol agents. Annual Review of Phytopathology, v.48, p.21-43, 2010. DOI: http://dx.doi.org/10.1146/annurev-phyto-073009-114450.

SMITH, S.E.; READ, D.J. Mycorrhizal Symbiosis. $3^{\text {rd }}$ ed. London: Academic Press, 2008. 145-187p.

SMITH, S.E.; SMITH, F.A. Fresh perspectives on the roles of arbuscular mycorrhizal fungi in plant nutrition and growth. Mycologia, v.104, p.1-13, 2012. DOI: http://dx.doi.org/10.3852/11229.

SMITH, S.E.; SMITH, F.A. Roles of arbuscular mycorrhizas in plant nutrition and growth: new paradigms from cellular to ecosystem scales. Annual Review of Plant Biology, v.62, p.227-250, 2011. DOI: http://dx.doi.org/10.1146/annurevarplant-042110-103846.

SOLAIMAN, M.Z.; EZAWA, T.; KOJIMA, T.; SAITO, M. Polyphosphates in intraradical and extraradical hyphae of an arbuscular mycorrhizal fungus, Gigaspora margarita. Applied and Environmental Microbiology, v.65, p.5604-5606, 1999. Available at: <http://aem.asm.org/content/65/12/5604.abstract $>$. Accessed on: Aug. 162016.

SOLAIMAN, M.Z.; SAITO, M. Phosphate efflux from intraradical hyphae of Gigaspora margarita in vitro and its implication for phosphorus translocation. New Phytologist, v.151, p.525-533, 2001. DOI: http://dx.doi.org/10.1046/j.0028-646x.2001.00182.x.

SPERANDIO, M.V.L.; SANTOS, L.A.; BUCHER, C.A.; FERNANDES, M.S.; SOUZA, S.R. de. Isoforms of plasma membrane $\mathrm{H}^{+}$-ATPase in rice root and shoot are differentially induced by starvation and resupply of $\mathrm{NO}_{3}^{-}$or $\mathrm{NH}_{4}^{+}$. Plant 
Science, v.180, p.251-258, 2011. DOI: http://dx.doi.org/10.1016/j. plantsci.2010.08.018.

STOYKE, G.; CURRAH, R.S. Endophytic fungi from the mycorrhizae of alpine ericoid plants. Canadian Journal of Botany, v.69, p.347-352, 1991. DOI: http://dx.doi.org/10.1139/b91047.

STRUCK, C.; HAHN, M.; MENDGEN, K. Plasma membrane $\mathrm{H}^{+}$ATPase activity in spores, germ tubes, and haustoria of the rust fungus Uromyces viciae-fabae. Fungal Genetics and Biology, v.20, p.30-35, 1996. DOI: http://dx.doi.org/10.1006/fgbi.1996.0006.

SUBRAMANIAN, K.S.; CHAREST, C. Arbuscular mycorrhizae and nitrogen assimilation in maize after drought and recovery. Physiologia Plantarum, v.102, p.285-296, 1998. DOI: http://dx.doi.org/10.1034/j.1399-3054.1998.1020217.x.

TAIZ, L.; ZEIGER, E.; MØLLER, I.M.; MURPHY, A. Fisiologia e desenvolvimento vegetal. 6.ed. Porto Alegre: Artmed, 2017. $888 \mathrm{p}$.

TANAKA, Y:; YANO, K. Nitrogen delivery to maize via mycorrhizal hyphae depends on the form of $\mathrm{N}$ supplied. Plant, Cell \& Environment, v.28, p.1247-1254, 2005. DOI: http://dx.doi.org/10.1111/j.1365-3040.2005.01360.x.

TEMPLE, S.J.; VANCE, C.P.; GANTT, J.S. Glutamate synthase and nitrogen assimilation. Trends in Plant Science, v.3, p.51-56, 1998. DOI: http://dx.doi.org/10.1016/S1360-1385(97)01159-X.

THOMSON, B.D.; CLARKSON, D.T.; BRAIN, P. Kinetics of phosphorus uptake by the germ-tubes of the vesicular-arbuscular mycorrhizal fungus, Gigaspora margarita. New Phytologist, v.116, p.647-653, 1990. DOI: http://dx.doi.org/10.1111/j.1469-8137.1990.tb00550.x.

TIAN, C.; KASIBORSKI, B.; KOUL, R.; LAMMERS, P.J.; BÜCKING, H.; SHACHAR-HILL, Y. Regulation of the nitrogen transfer pathway in the arbuscular mycorrhizal symbiosis: gene characterization and the coordination of expression with nitrogen flux. Plant Physiology, v.153, p.1175-1187, 2010. DOI: http://dx.doi.org/10.1104/pp.110.156430.

TISSERANT, E.; KOHLER, A.; DOZOLME-SEDDAS, P.; BALESTRINI, R.; BENABDELLAH, K.; COLARD, A.; CROLL, D.; SILVA, C. da; GOMEZ, S.K.; KOUL, R.; FERROL, N.; FIORILlI, V.; FORMEY, D.; FRANKEN, Ph.; HELBER, N.; HIJRI, M.; LANFRANCO, L.; LINDQUIST, E.; LIU, Y.; MALBREIL, M.; MORIN, E.; POULAIN, J.; SHAPIRO, H.; VAN TUINEN, D.; WASCHKE, A.; AZCÓN-AGUILAR, C.; BÉCARD, G.; BONFANTE, P.; HARRISON, M.J.; KÜSTER, H.; LAMMERS, P.; PASZKOWSKI, U.; REQUENA, N.; RENSING, S.A.; ROUX, C.; SANDERS, I.R.; SHACHARHILL, Y.; TUSKAN, G.; YOUNG, J.P.W.; GIANINAZZIPEARSON, V.; MARTIN, F. The transcriptome of the arbuscular mycorrhizal fungus Glomus intraradices (DAOM 197198) reveals functional tradeoffs in an obligate symbiont. New Phytologist, v.193, p.755-769, 2012. DOI: http://dx.doi.org/10.1111/j.14698137.2011.03948.x.

TISSERANT, E.; MALBREIL, M.; KUO, A.; KOHLER, A.; SYMEONIDI, A.; BALESTRINI, R.; CHARRON, P.; DUENSING, N.; FREI DIT FREY, N.; GIANINAZZIPEARSON, V.; GILBERT, L.B.; HANDA, Y.; HERR, J.R.;
HIJRI, M.; KOUL, R.; KAWAGUCHI, M.; KRAJINSKI, F.; LAMMERS, P.J.; MASCLAUX, F.G.; MURAT, C.; MORIN, E.; NDIKUMANA, S.; PAGNI, M.; PETITPIERRE, D.; REQUENA, N.; ROSIKIEWICZ, P.; RILEY, R.; SAITO, K.; SAN CLEMENTE, H.; SHAPIRO, H.; VAN TUINEN, D.; BÉCARD, G.; BONFANTE, P.; PASZKOWSKI, U.; SHACHAR-HILL, Y.Y.; TUSKAN, G.A.; YOUNG, J.P.W.; SANDERS, I.R.; HENRISSAT, B.; RENSING, S.A.; GRIGORIEV, I.V.; CORRADI, N.; ROUX, C.; MARTIN, F. Genome of an arbuscular mycorrhizal fungus provides insight into the oldest plant symbiosis. Proceedings of the National Academy of Sciences, v.110, p.20117-20122, 2013. DOI: http://dx.doi.org/10.1073/pnas.1313452110.

USUKI, F.; NARISAWA, K. A mutualistic symbiosis between a dark septate endophytic fungus, Heteroconium chaetospira, and a nonmycorrhizal plant, Chinese cabbage. Mycologia, v.99, p.175184, 2007. DOI: http://dx.doi.org/10.1080/15572536.2007.11832577.

VANCE, C.P.; UHDE-STONE, C.; ALLAN, D.L. Phosphorus acquisition and use: critical adaptations by plants for securing a nonrenewable resource. New Phytologist, v.157, p.423-447, 2003. DOI: http://dx.doi.org/10.1046/j.1469-8137.2003.00695.x.

VARMA, A.; VERMA, S.; SUDHA; SAHAY, N.; BÜTEHORN, B.; FRANKEN, P. Piriformospora indica, a cultivable plantgrowth-promoting root endophyte. Applied and Environmental Microbiology, v.65, p.2741-2744, 1999. Available at: $<$ https://aem. asm.org/content/aem/65/6/2741.full.pdf $>$. Accessed on: Apr. 30 2016.

VÁZQUEZ, M.; BAREA, J.M.; AZCÓN, R. Impact of soil nitrogen concentration on Glomus spp.-Sinorhizobium interactions as affecting growth, nitrate reductase activity and protein content of Medicago sativa. Biology and Fertility of Soils, v.34, p.57-63, 2001. DOI: http://dx.doi.org/10.1007/s003740100373.

VERGARA, C.; ARAUJO, K.E.C.; ALVES, L.S.; SOUZA, S.R. de; SANTOS, L.A.; SANTA-CATARINA, C.; SILVA, K. da; PEREIRA, G.M.D.; XAVIER, G.R.; ZILLI, J.É. Contribution of dark septate fungi to the nutrient uptake and growth of rice plants. Brazilian Journal of Microbiology, v.49, p.67-78, 2018a. DOI: http://dx.doi.org/10.1016/j.bjm.2017.04.010.

VERGARA, C.; ARAUJO, K.E.C.; URQUIAGA, S.; SANTA-CATARINA, C.; SCHULTZ, N.; ARAUJO, E. da S.; BALIEIRO, F. de C.; XAVIER, G.R.; ZILLI, J.É. Dark septate endophytic fungi increase green manure $-{ }^{15} \mathrm{~N}$ recovery efficiency, $\mathrm{N}$ contents, and micronutrients in rice grains. Frontiers in Plant Science, v.9, art.613, 2018b. DOI: http://dx.doi.org/10.3389/fpls.2018.00613.

VERSAW, W.K. A phosphate-repressible, high-affinity phosphate permease is encoded by the pho-5+ gene of Neurospora crassa. Gene, v.153, p.135-139, 1995. DOI: http://dx.doi.org/10.1016/03781119(94)00814-9.

VIERECK, N.; HANSEN, P.E.; JAKOBSEN, I. Phosphate pool dynamics in the arbuscular mycorrhizal fungus Glomus intraradices studied by in vivo ${ }^{31} \mathrm{P}$ NMR spectroscopy. New Phytologist, v.162, p.783-794, 2004. DOI: http://dx.doi. org/10.1111/j.1469-8137.2004.01048.x.

VOLPE, V.; DELL'AGLIO, E.; BONFANTE, P. The Lotus japonicus MAMI gene links root development, arbuscular 
mycorrhizal symbiosis and phosphate availability. Plant Signaling \& Behavior, v.8, e23414, 2013. DOI: http://dx.doi.org/10.4161/psb.23414.

VOLPE, V.; GIOVANNETTI, M.; SUN, X.-G.; FIORILLI, V.; BONFANTE, P. The phosphate transporters LjPT4 and MtPT4 mediate early root responses to phosphate status in non mycorrhizal roots. Plant, Cell \& Environment, v.39, p.660-671, 2016. DOI: http://dx.doi.org/10.1111/pce.12659.

WANG, E.; SCHORNACK, S.; MARSH, J.F.; GOBBATO, E.; SCHWESSINGER, B.; EASTMOND, P.; SCHULTZE, M.; KAMOUN, S.; OLDROYD, G.E.D. A common signaling process that promotes mycorrhizal and oomycete colonization of plants. Current Biology, v.22, p.2242-2246, 2012. DOI: http://dx.doi.org/10.1016/j.cub.2012.09.043.

WANG, E.; YU, N.; BANO, S.A.; LIU, C.; MILLER, A.J.; COUSINS, D.; ZHANG, X.; RATET, P.; TADEGE, M.; MYSORE, K.S.; DOWNIE, J.A.; MURRAY, J.D.; OLDROYD, G.E.D.; SCHULTZE, M. A $\mathrm{H}^{+}$-ATPase that energizes nutrient uptake during mycorrhizal symbioses in rice and Medicago truncatula. The Plant Cell, v.26, p.1818-1830, 2014. DOI: http://dx.doi.org/10.1105/tpc.113.120527.

WEI, Y.-F.; LI, T.; LI, L.-F.; WANG, J.-L.; CAO, G.-H.; ZHAO, Z.-W. Functional and transcript analysis of a novel metal transporter gene EpNramp from a dark septate endophyte (Exophiala pisciphila). Ecotoxicology and Environmental Safety, v.124, p.363-368, 2016. DOI: http://dx.doi.org/10.1016/j. ecoenv.2015.11.008.

XIE, X.; HUANG, W.; LIU, F.; TANG, N.; LIU, Y.; LIN, H.; ZHAO, B. Functional analysis of the novel mycorrhiza-specific phosphate transporter AsPT1 and PHT1 family from Astragalus sinicus during the arbuscular mycorrhizal symbiosis. New Phytologist, v.198, p.836-852, 2013. DOI: http://dx.doi.org/10.1111/nph.12188.
XIE, X.; LIN, H.; PENG, X.; XU, C.; SUN, Z.; JIANG, K.; HUANG, A.; WU, X.; TANG, N.; SALVIOLI, A.; BONFANTE, P.; ZHAO, B. Arbuscular mycorrhizal symbiosis requires a phosphate transceptor in the Gigaspora margarita fungal symbiont. Molecular Plant, v.9, p.1583-1608, 2016. DOI: http://dx.doi.org/10.1016/j.molp.2016.08.011.

YANG, S.-Y.; GRØNLUND, M.; JAKOBSEN, I.; GROTEMEYER, M.S.; RENTSCH, D.; MIYAO, A.; HIROCHIKA, H.; KUMAR, C.S.; SUNDARESAN, V.; SALAMIN, N.; CATAUSAN, S.; MATTES, N.; HEUER, S.; PASZKOWSKI, U. Nonredundant regulation of rice arbuscular mycorrhizal symbiosis by two members of the PHOSPHATE TRANSPORTERl gene family. The Plant Cell, v.24, p.4236-4251, 2012. DOI: http://dx.doi.org/10.1105/tpc.112.104901.

YUAN, Z.-L.; SU, Z.-Z.; MAO, L.-J.; PENG, Y.-Q.; YANG, G.M.; LIN, F.-C.; ZHANG, C.-L. Distinctive endophytic fungal assemblage in stems of wild rice (Oryza granulata) in China with special reference to two species of Muscodor (xylariaceae). The Journal of Microbiology, v.49, p.15-23, 2011. DOI: http://dx.doi.org/10.1007/s12275-011-0213-3.

ZHANG, H.-H.; TANG, M.; CHEN, H.; WANG, Y.-J. Effects of a dark-septate endophytic isolate LBF-2 on the medicinal plant Lycium barbarum L. The Journal of Microbiology, v.50, p.91-96, 2012. DOI: http://dx.doi.org/ 10.1007/s12275-012-1159-9.

ZHANG, Q.; GONG, M.; YUAN, J.; HOU, Y.; ZHANG, H.; WANG, Y.; HOU, X. Dark septate endophyte improves drought tolerance in Sorghum. International Journal of Agriculture \& Biology, v.19, p.53-60, 2017. DOI: http://dx.doi.org/10.17957/ IJAB/15.0241.

\section{ERRATA: Plant-mycorrhizal fungi interaction and response to inoculation with different growth-promoting fungi}

In the paper "Plant-mycorrhizal fungi interaction and response to inoculation with different growth-promoting fungi", DOI: 10.1590/S1678-3921.pab2019.v54.25140, published in Pesquisa Agropecuária Brasileira, v.54, e25140, 2019, on page 1, left column, line 5, where it reads:

“Orivaldo José Jaggin Júnior”, it should read: “Orivaldo José Saggin Júnior”. 